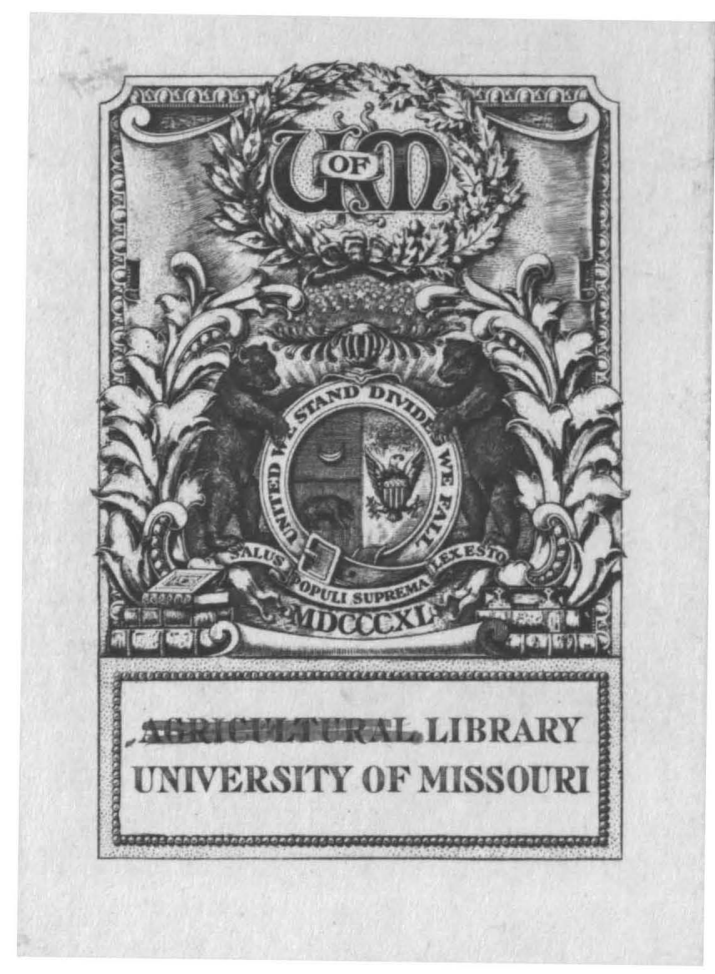

This Thesis Has Been

MICROFILMED

Negative No. T. $\quad 48 R$

Form 26 
THE EFTICIENCY OF THE FARM DIARY

IN ACCOUNTING INVESTIGATIONS

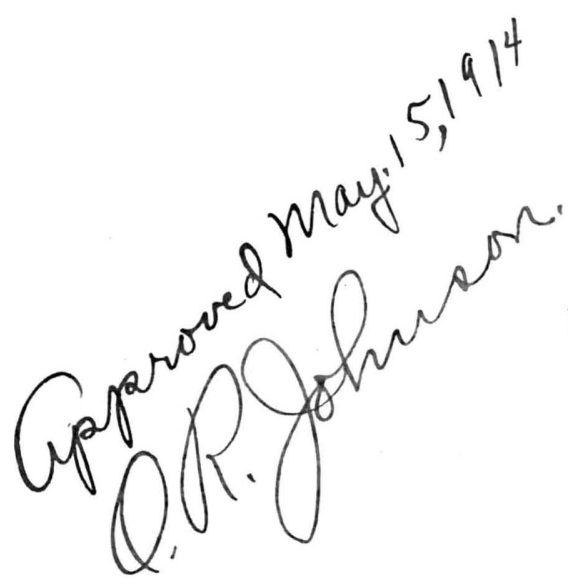

by

W1111am E. Foard, B.S.

SUBMITTED IN PARTIAI FULFILIMENT OF THE

REQUIREMENTS FOR THE DEGREE OF

MASTER OF ARTS

in the

GRADUATE SCHOOI

of the

UNIVERSITY OF MISSOURI 


\section{ACKNOWLEDGEIMENT .}

The writer is greatly indebted to the following men: R. E. Kirchner; J.W.Ezell; W. M. Roberts; I.N. Gartin; H. R. Frink; Robert Flaspohler; W. A. Ruggles; Geo. Kime; and James 0. Erwin. Only by the co-operation of these men in keeping the Farm Diary has this study been made possible. 
INDEX .

Page

Reason for Presenting the Diary liethod....... 1 .

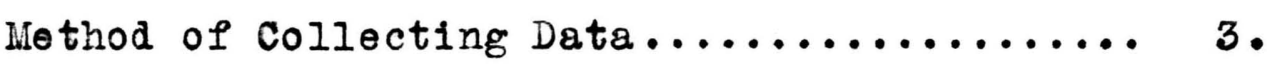

Method of Tabulating Data.............. 8 .

Illustrative Iedger Accounts

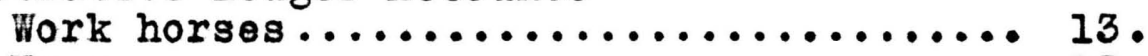

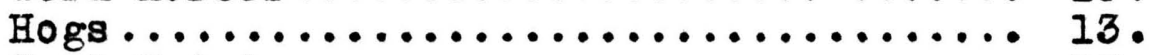

Real Estate ..................... 17.

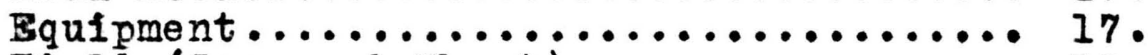

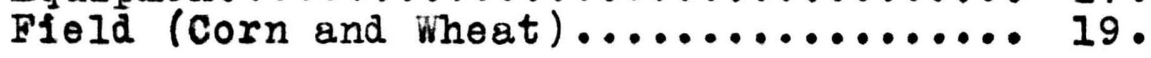

Annual summary..................... 20.

Miscellaneous Tables................... 36 .

Cost of Production.................... 52 .

Conclusion..........................61...

\section{IIIUSTRATIONS .}

Plate I, A Daily Report................. 5.

Plate II. A Monthly Chore and Feed Statement 7 .

Plate III. A Miscellaneous Labor Sheet...... 9 .

Plate IV. A Field Labor Sheet............ 10 .

Plate $\nabla$. Iength of Work Day for Man and Horse 43.

Plate VI. Iength of Work Day per Farm...... 44 .

Plate VII. Feed Cost of Work Horses Compared with Iabor They Do........... 47 . 


\section{INTRODUCTION •}

As stated in the subject, the purpose of this paper is to set forth the efficiency in accounting investigations of the Diary system of keeping Farm records. This system of keoping farm records is known as the farm diary. It has been used to a certain extent and in a modified form by farmers over the country, but it has been used very little, if any, as a means of securing data for investigational purposes, except in a small way by the Nepartmentiat Washington. The diary has been used in M1ssourl by the farmers in co-operation with the Farm Management Department of the University for the past two jears with increasing popularity among both the farmers and the Department. S1x farmers co-operated in this work in 1912, twenty in 1913, and more than forty have begun the work for 1914.

All tables, tabulations and results shown herein are given for the purpose of showing the;possibilities of this syatem of keeping farm records, rather than the intention of presenting data from which any definite conclusions can be drawn, because of the small number of records from wich this data has been collected. AII data shown here is gathered from six diaries kept in 1912, and Iive which were kept in 1913; the year having been completed February 28th, 1914. In some cases it was possible to use the eleven farms in the tabulations, while in others the data was not complete enough In all farms, but with oach table is given the number of farms and animals included. 
THE WIPICIENCY OF THE FARM DIARY

IN ACCOUNTING INVESTIGATIONS

\section{REASONS FOR PRESENTING THE DIARY METHOD.}

The farm diary appeals to the farmer because of it's simplicity, and to the investigator because of the thoroughness of the record, it's condensed form and the economy and rapidity with which records can be secured.

There is an urgent demand among farmers for a simple system of farm records; one they can understand with a little study; one that requires as little work as possible to keop and at the same time one from which the farmer himself can get something worth while. The best records can be secured only from farmers who are deeply interested in this work, and there are few farmers who will become enthused over farm records unless they are convinced that they get value received for what they put into the work. Nor can they be criticised for this attitude. If valuable and reliable data can be secured for investigational purposes and at the same time the farmer helped to more efficient farm management, by pointing out to him, as his records will show, the practices on his farm that are profitable and, also, those that are losing him money, it certainly seems that this should be done. It undoubtly is as important that the Agricultural Colleges should teach the farmers the business side of farming as well as teach them how to produce more grain, cattle and hogs. For how can a man know how to best take care of what he produces, 
or know the cost of producing his products without being famlliar with the business side of his operations.

There is a demand all over the country for some simple and practical system of keeping farm records. Many publishing houses are feeling this demand and they are responding by putting out sets of books and systems of farm records, but most of these are too complicated and conform too closely to the commercial system of book-keeping to be applicable to the average farmer. It is felt that the farm diary will meet the needs of both the farmer and the investigator, and indeed it will be hard to meet the needs of one without meeting the needs of both.

In the past, two systems of collecting data for accounting investigations have been used extensively by the Farm Management Department at Washington, D.C., and also by the different Experiment Stations and colleges. These are: first, The Survey; and second, The Detalled Daily Records. Surveys are made by going to the district from which data is desired and securing a large number of records. These records are estimates and of course a large number are essential since results are determined on averages. The detailed daily record system is very complete especially in reporting the labor, yet it is so detailed and requires so much attention on the farmer's part, that few men have the patience to carry on the work. Then too, so few records can be secured in any one jear that they are of much less value than if a great number of records can be gotten in the same year. It is believed that the farm diary overcomes 
these objections to the other systems because the diary can be made just as thorough and as much in detail as the daily system and also several times as many diaries can be taken care of with the same expense.

\section{METHOD OF COLLECTING DATA.}

It seems advisable at this time to explain, somewhat in detail, the diary and the means of securing the desired information through it. Also it will be compared with other systems of collecting data and it's advantages over them pointed out.

Before beginning to keep farm records two things are necessary, namely: The making of a complete map of the farm including the lettering of each fleld, and the taking of a complete inventory of everything on the farm. There are three divisions of the records that it is absolutely necessary to keep in order to have a complete record of all operations on a farm. These are a daily labor record, a financial record and a feeding record.

The Farm Diary is a single book and good for one year's record. It has places for first and second inventory, map of farm, and places also for the three necessary kinds of record mentioned above. This allows for the recording of the data in much less time than where it is necessary to turn to a different book or blank to record the different items, as it is necessary to do in the detalled dally and other systems. Furthermore, by the use of the diary one has his entire record between two covers which 
makes it so much more convenient for future referenco.

In plate No. 1, Is shown a sample daily record taken from a diary. The record on this plate as well as on others that follow is the exact record of a co-operator who kept a diary in 1913, and is not fictitious nor an ideal. A page like this is used in the diary for each day in the year. Notice how much in detall this man has gone in giving the number of horses used, size and kind of tools used, kind and amount of seed used together with price. This is a very complete record, Jet it has not taken the farmer long to record these things in the evening of the same day while they are fresh in his memory. The amount of eggs, butter, milk, vegetables, etc., received or used in the home is recorded on the daily sheet, or may be entered at the end of. the week. By kmowing these things it is possible to get the cost of the family living on the farm and to find out how much the farm furnishes towards this cost in provisions. Then the farm can be given credit for same. This is a point that heretofore has not been worked out nor has it scarcely been attempted. Since the farmer gets this book to keep, after the information has been secured, he jots down many things of interest as to the weather, breeding of stock, birth of young etc. These things makes the book more valuable to the farmer and hence he takes more interest in the work. No matter how many men may be working the labor of all is reported on this one sheet, and still each man's Iabor kept separate. 
5

Plate I.

DAY: Thuredoy

DATE: MaY 29, 1913PAGE:

Rob harrowed; 4 horren 10 ftharrow field $\theta$

HOURS
MAN HORSE

"Alowed 4 ". 12"gang

Aplowed 14"walking plow 2 horkes

Rob. harroved ahead of plauter

" took painter Efcitoic laddere

to Ford city

I planted yellow deit' cloypear

Dear at the rate of , hw. to 10 acree "260 forhw." " 36

Very hot. Semp qio

23 egge.

Sold 30 dog egge $c 15 \phi$

Ethel shoce and tockinge

Bought dry goods

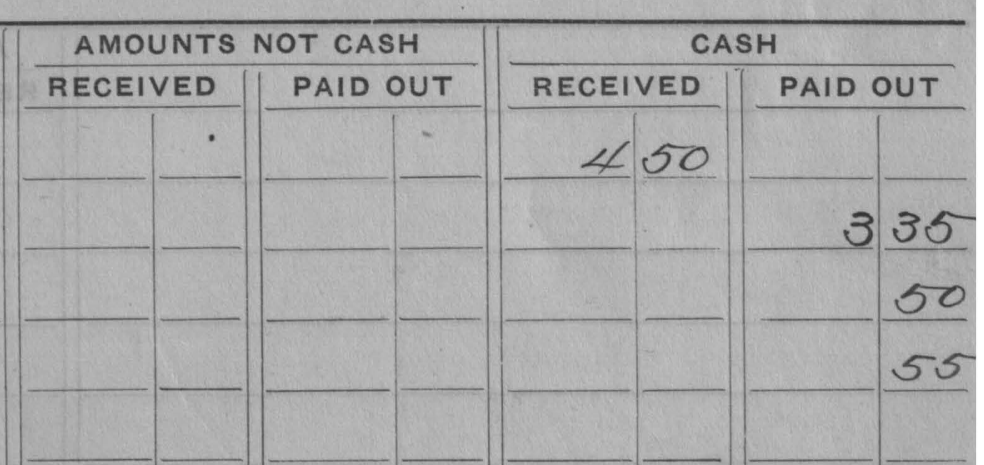


The lower portion on the page shown on plate No. 1 is used for recording any financial transactions, whether cash or otherwise. It is impossible to keep a correct financial account unless this is attended to each day. With the diary this is done. The labor record is taken care of each day and since the place for recording the financial transactions is on the same sheet, this is also carefully attended to. While, where a different book is used for the financial record, a week or more often elapse between times of making entries, and it is impossible in that way to get anything like a correct record. The Department keeps in touch with each co-operator by having him send in to the office from time to time as he is asked, duplicate reports of different day's records. A number of blank duplicates are inserted in the back of each diary for this purpose. Plate No. 2 shows a chore and feed statement which is made out monthly. All chore work is reported on this sheet by giving the average number of hours per day put in on the different classes of live stock, By timing himself a day or two the farmer can get this very accurate, as in most any one month he will put in practically the same amount of time per day. Any extra work on stock is reported on the daily record. The second part of plate no. 2 shows a feed record for one month. The feeding record is the most difficult of all to keep accurate and more farmers fail on this than any other one thing. It is desired to keep both the chore and feed record separate on the differ- 
MONTH:

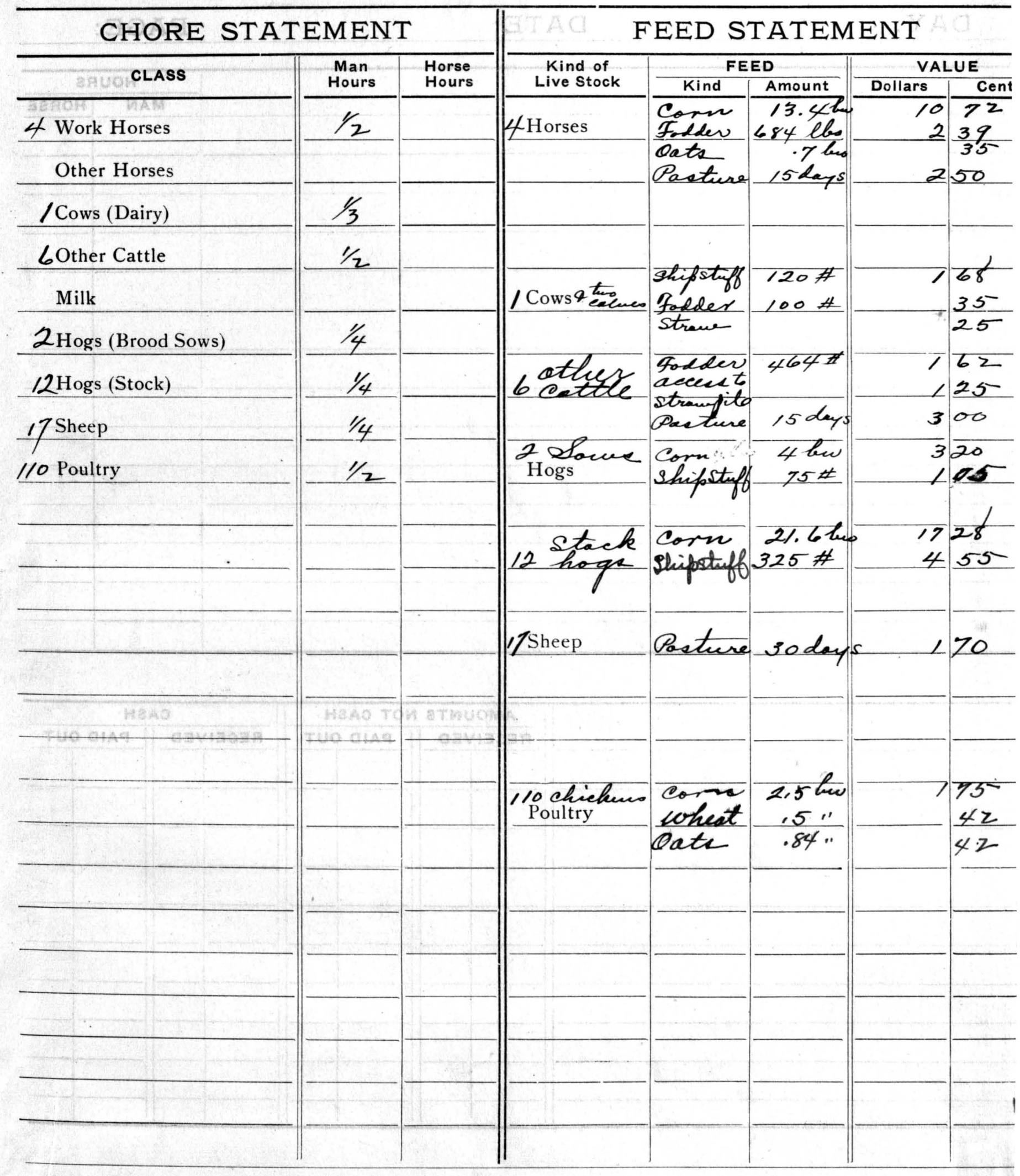


ent classes of stock. For example, keep work horses separate from other horses, milk cows separate from other cattle, and brood sows separate from other hogs . All co-operators make these distinctions where it is possible to do so. This makes it possible then, to work out the cost of keep of work horses, cows, sows and other stock; also the cost of horse labor. Tables will be given later to bring out these points.

\section{METHOD OF TABUI TING DATA.}

After having briefly described the method of collecting data, the compiling of same for investigational purposes will be considered. The labor is divided into miscellaneous and field, and each is posted on separate blanks. plate No. 3 shows the miscellaneousıon a farm for the month of May. Notice the classifications into which this labor is divided. The total field labor per day is carried to this sheet and the total labor per day secured. Also the total miscellaneous, total field, and grand total labor for the month, for both man and horse, is determined. Plate No . 4 shows the field labor per operations of a corn field. The labor of each crop on a farm is posted in this manner. From these sheets it is possible, not only to find the labor cost per acre of the several crops, but also the labor cost per operation, such as ploughing, harrowing, discing and cultivation. Furthermore, the seasonal distribution of labor is studied from these sheets. 
Plate III

LABOR DISTRIBUTION Farm of P.W.Gell

Sheet No.

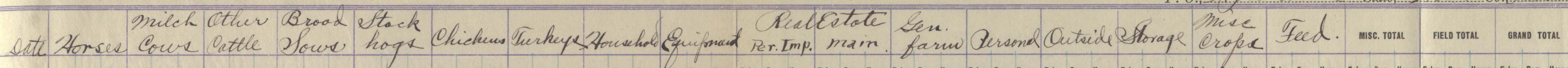

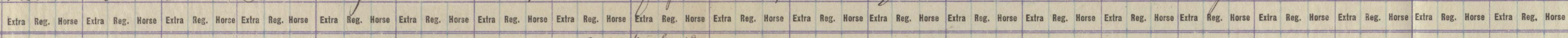

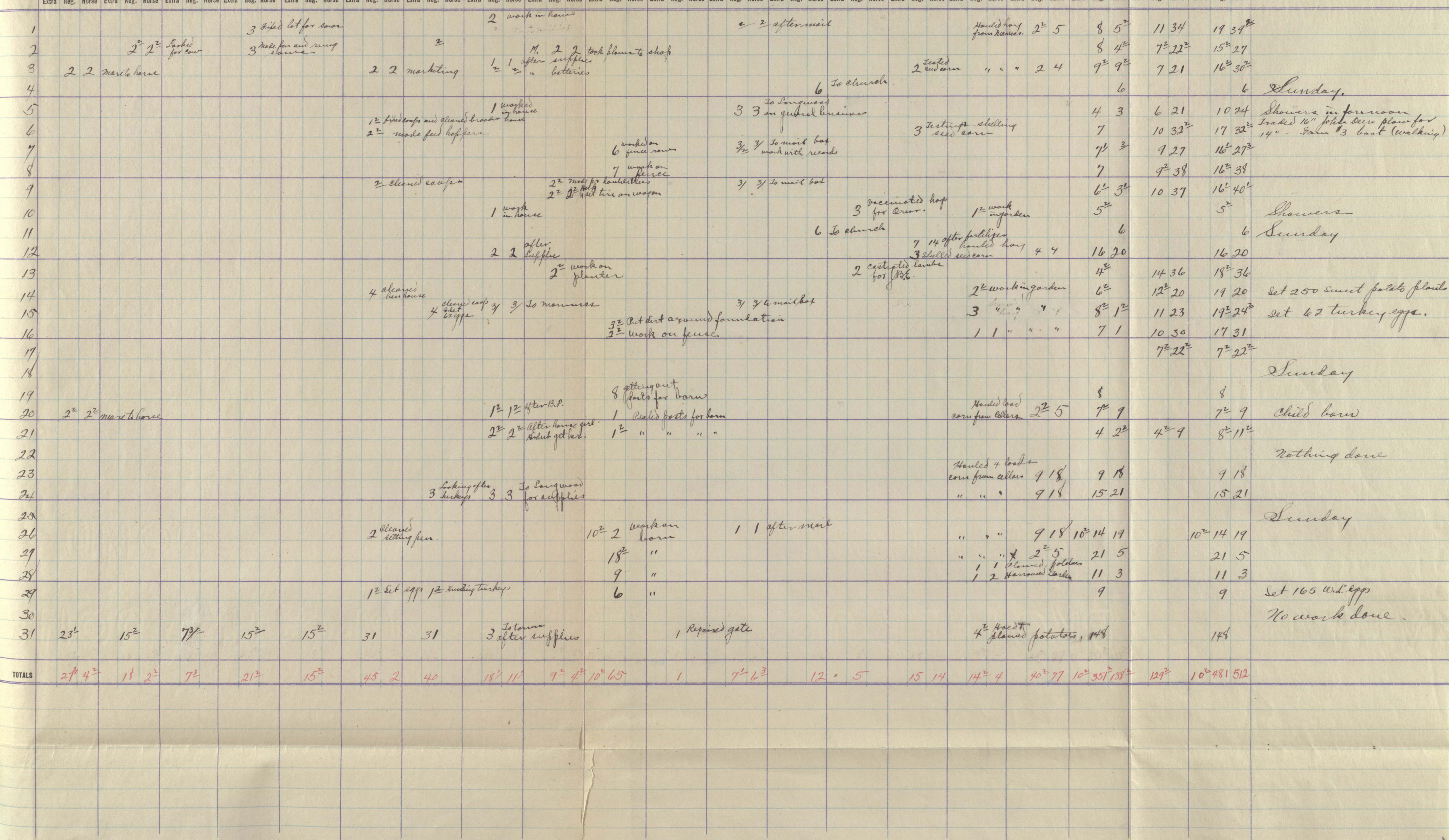


Plate IV $\quad$ LABOR DISTRIBUTION Farm of fol, Eel

COLLEGE OF AG

10 Acres

LABOR DISTRIBUTION P. Pf Af ow tonic State,

the. Co., Retire Month

Sheet No.

\begin{tabular}{l} 
mISC. TOTAL FIELD TOTAL GRAND TOTAL \\
\hline
\end{tabular}

191.3

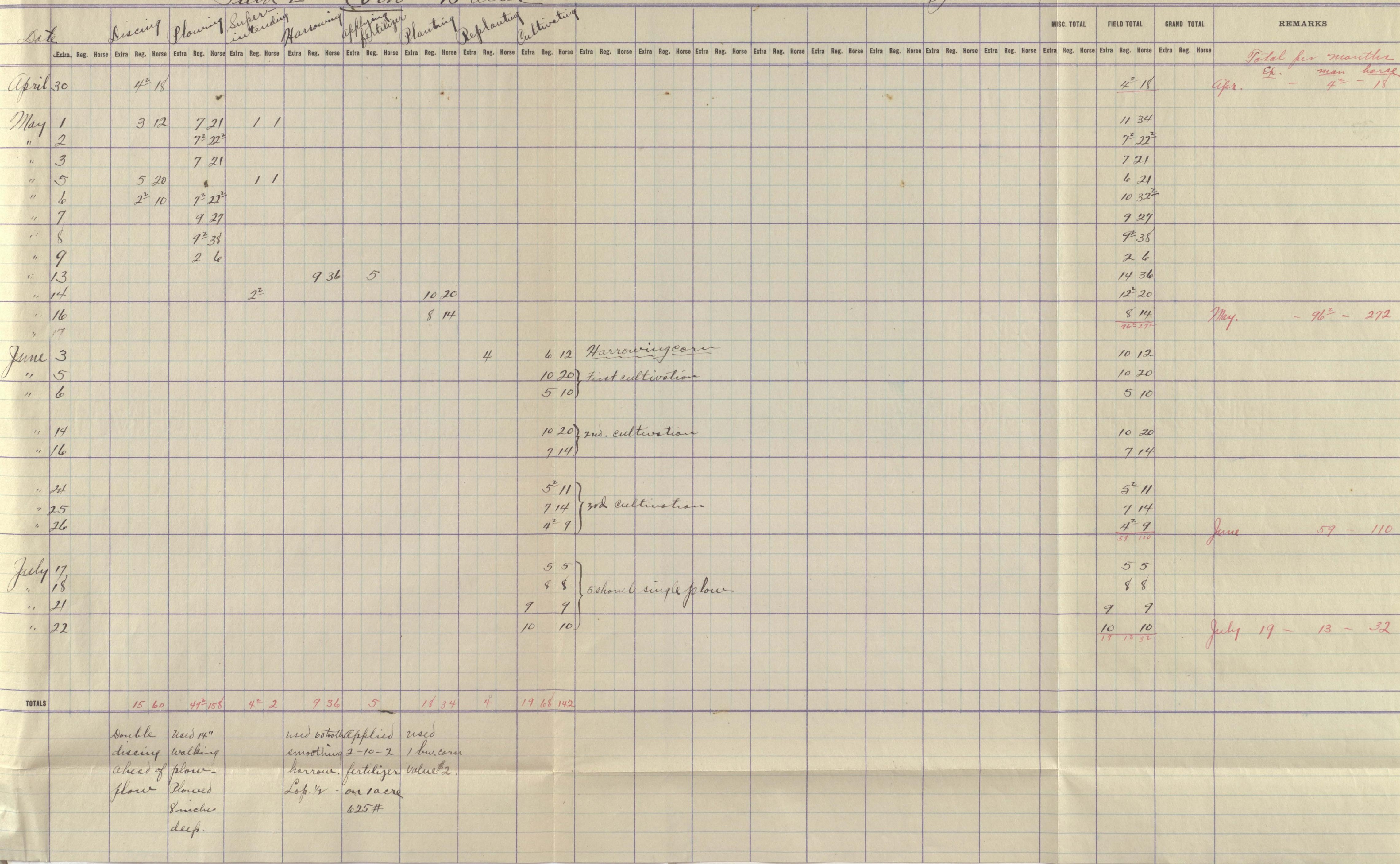


The labor classification used here is the same as that used in some previous work done in the Farm Management Department. 1

Besides the labor sheets already shown (plates III and IV), the only other form on which the records are posted for permanency is the ledger. All financial records are posted direct from the diary to the ledger. At the close of the year all crop jields, feed fed, interest at $5 \%$ on investment, taxes, house-rent, both horse and man labor and all other items necessary, are posted to the proper account in the ledger. The ledger accounts include the accounts found on the miscellaneous labor sheet except the storage and miscellaneous crops which are distributed. Additional accounts are cash, bills payable, and bills receivable, together with an account with each field. As an example of how these ledger accounts are handled, and to give some idea of their value, a number of representative accounts are shown here in the form of tables, and each will be briefly explained.

Table No. I, 1llustrates a work horse account. This is an important account because it is from this that the cost of the horse labor is computed. The inventory at the beginning of the jear is debited to the horse account; also all the expenses the horses incur during the year. For convenience the several little miscellaneous items of expense for the year are totaled and entered in one sum. The 267 hours of man labor is the total time put in on the horses for the jear. All man labor for the record from which these 
TABIE NO. 1.

WORK HORSES .

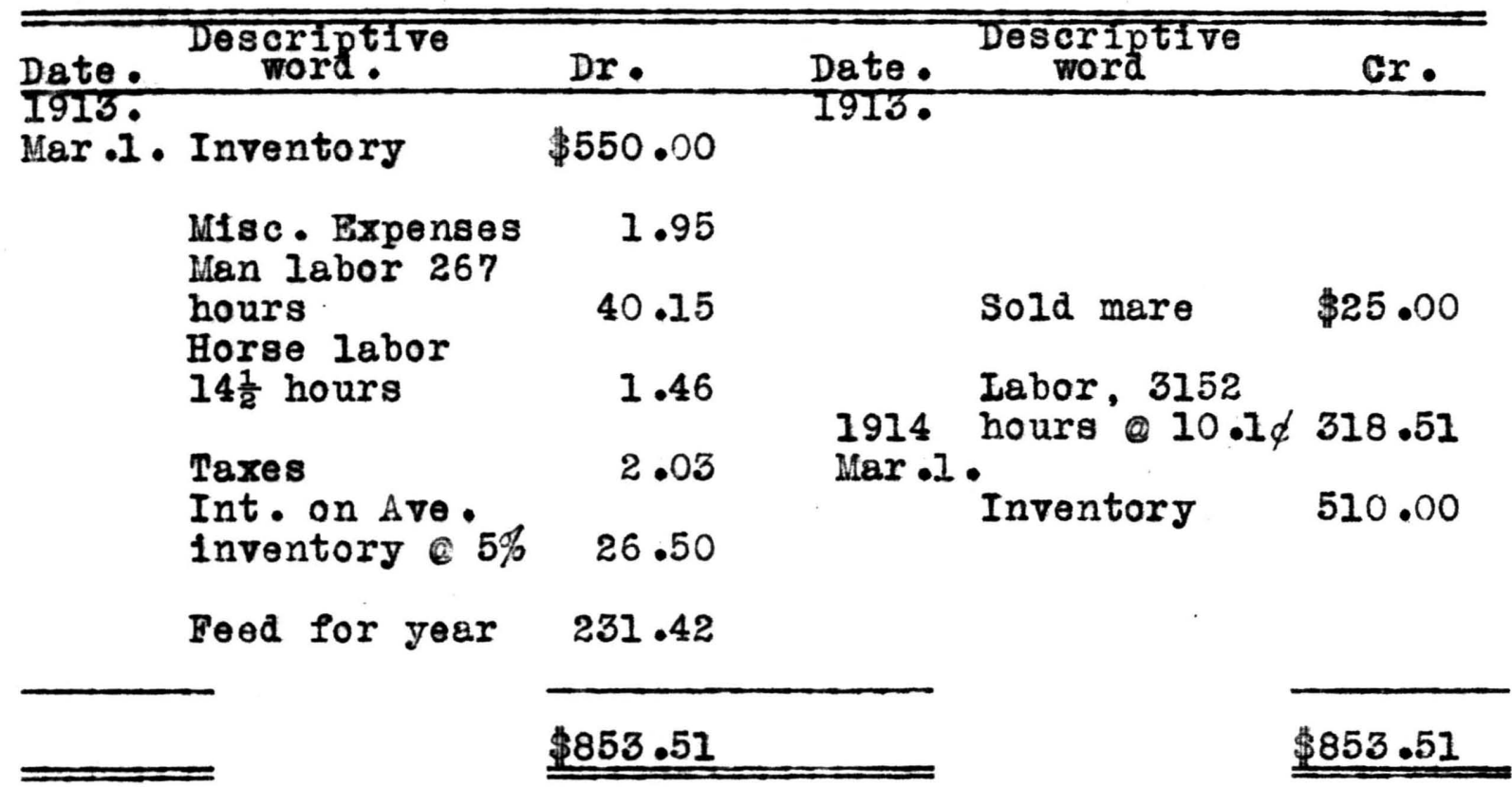

TABIE NO. II.

HOGS .

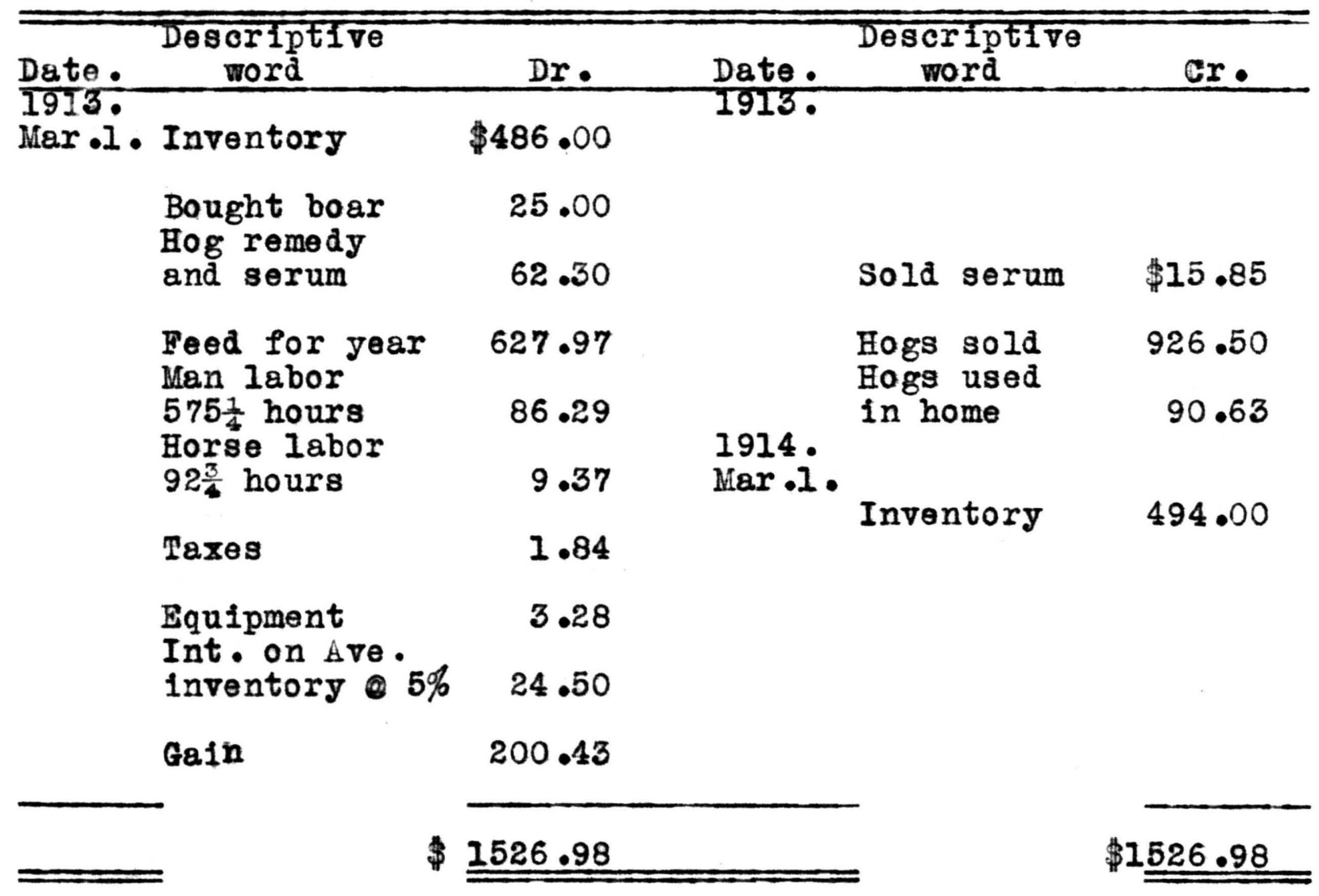


accounts were taken is charged at $15 \notin$ per hour. The horses, , as woll as all other classes of stock are charged with their portion of personal taxes based on the value of the first inventory. Five per-cent interest is figured on the everage inventory and each account charged with it's proportionate amount. The value of the feed is secured from the feeding record, a sample of which has been previously shown,(plate No. II.). The horses have not been debited with a depreciation charge as it seems preferable to let the inventory take care of any increase or decrease of value. Many farmers hand le their work stock so that the animals are disposed of before they depreciate very materfally in value, so under such a system it would not be fair to make a depreciation charge. Where work stock is kept on a farm until they become worthless, it is true that their depreciation is very great in a short time, but why not put the depreciation charge where it belongs. This only shows up the more unfavorably such a poor system of handing work stock.

The amount of labor put in by work horses in a year should balance their cost of keep. The loss in the horse account or the extent to which the debits exceed the credits is the cost of keep of the work stock. This cost divided by the total hours of labor done by the horses vill give the cost per hour of horse labor. But it will be noticed that the horses in this case have put in $14 \frac{1}{2}$ hours on themselves and before their total cost can be secured a rate is necessary in order to figure in the cost of these $14 \frac{1}{2}$ 
hours the horses have devoted to themselves. The total debits beforeading in the cost of the horse hours is $\$ 852.05$, and the total credits before the horses are given credit for their labor 1s $\$ 535.00$. The difforence is $\$ 317.05$, which is the cost of keoping the work horses less the value of the $14 \frac{1}{2}$ hours they have given to themselves. Now, if $14 \frac{1}{2}$ hours be taken from the total number of horse hours put in on the farm, which is 3152, there is left $3137 \frac{1}{2}$ hours - The $\$ 317.05$ divided by $3137 \frac{1}{2}$ hours will give the desired rate which is 10.1\& per hour. Then when we debit the account with $\$ 1.46$, which is the cost of the $14 \frac{1}{2}$ horse hours at $10.1 \not$, and when we credit the account with the total number of horse hours at $10.1 \phi$, the account balances. The cost of man labor on any farm is calculated at what it actually costs to hire regular help. For example, if you pay a hired man \$25.00 a month and board, valuing his board at $\$ 12.00$, this makes a total cost of $\$ 37.00$. If he works during the month 280 hours, it is only a simple problem in division to find what this man's labor costs per hour. In this case it would be $13.2 \phi$. The rate may be secured for any length of time or for any number of persons by simply dividing the total cost of labor by the total hours worked. Where no hired help is kept, a flat rate of $14 \varnothing$ is used as this is an average for Missouri's farm labor. Table No. II. shows a hog account; one that has made a good gain for the proprietor. We can always count 
on hogs making a good per-cent profit in Missouri if they are not attacked with cholera. It will not be necessary to explain each entry in this account as they conform closely to those found in the hor account above. Unless we understand just what is meant by the gain we may get the wrong impression and think it is too small. In figuring this gain not only has all cash and feed expenses been included, but all labor devoted to hogs as well as interest on investment at $5 \%$. The farmer has been paid for his only two investments, they are, labor and capital. So the gain here shown is a net gain. This shows that by feeding the crops to his hogs the farmer has made $\$ 200.00$ more than he would had he sold his crops, besides the labor he has gotten paid for and the manure which the animals produced. It is possible for a person to lose money on a field crop, and yet make a gain on his whole operation by running the crop through stock, that 1s, provided he gets pay for all labor he does.

Table No. III. shows a real-estate account, not exactly as it would be found in the ledger because here, for convenience, the expenses pertaining to maintenance and permanent improvement respectively, have been grouped together. The total maintenance of real-estate here shown is ${ }^{2} 211.83$. This includes $5 \%$ interest on real-estate, also taxes, equipment charge and any maintenance expense in the way of repairs. This sum is distributed to the fields on per acre basis under head of"use of land:" This account shows a gain of \$186.08 
TABIE NO. III.

REA I E T A T E.

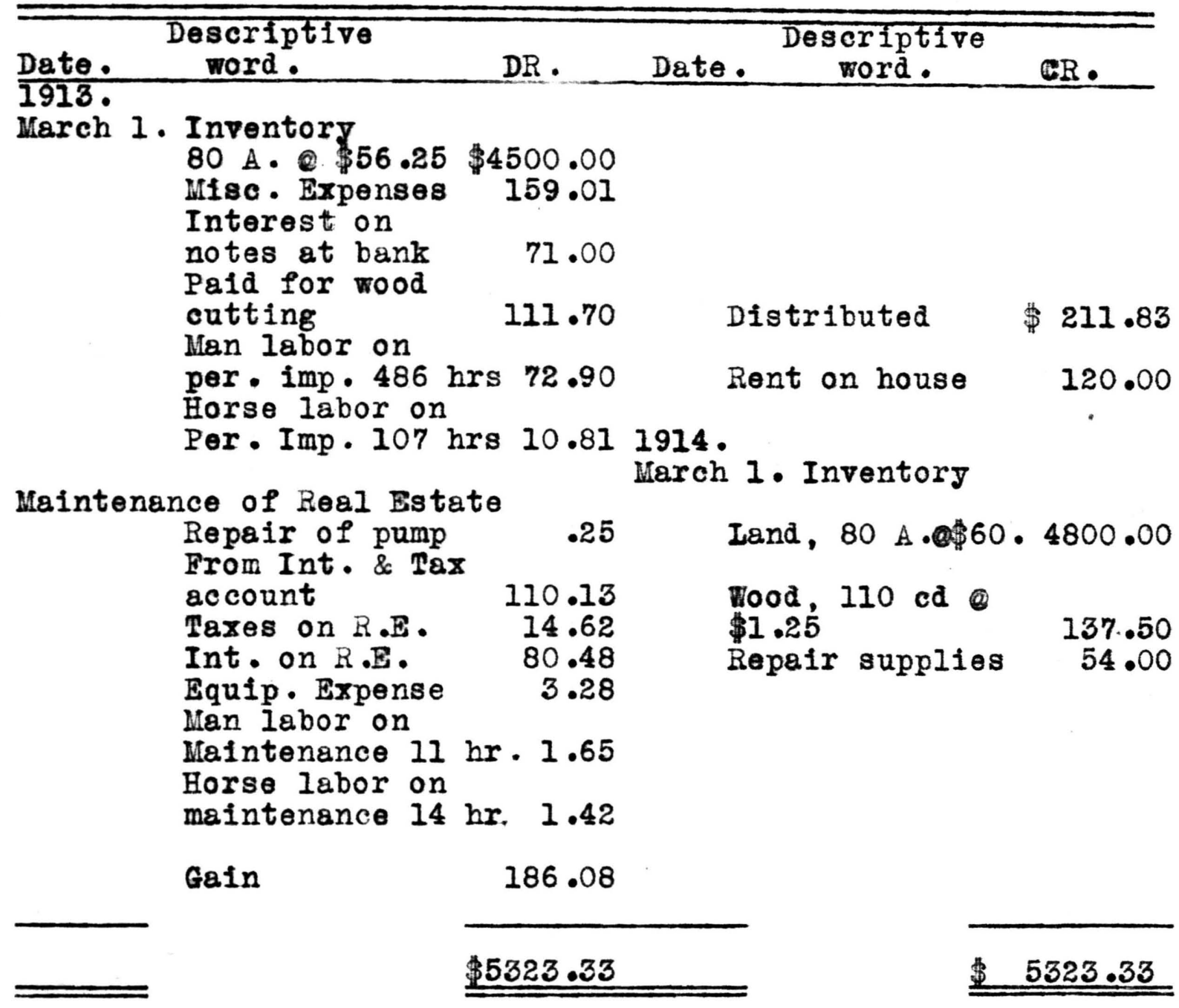

TABIE NO - IV.

B $Q$ U I P M E T

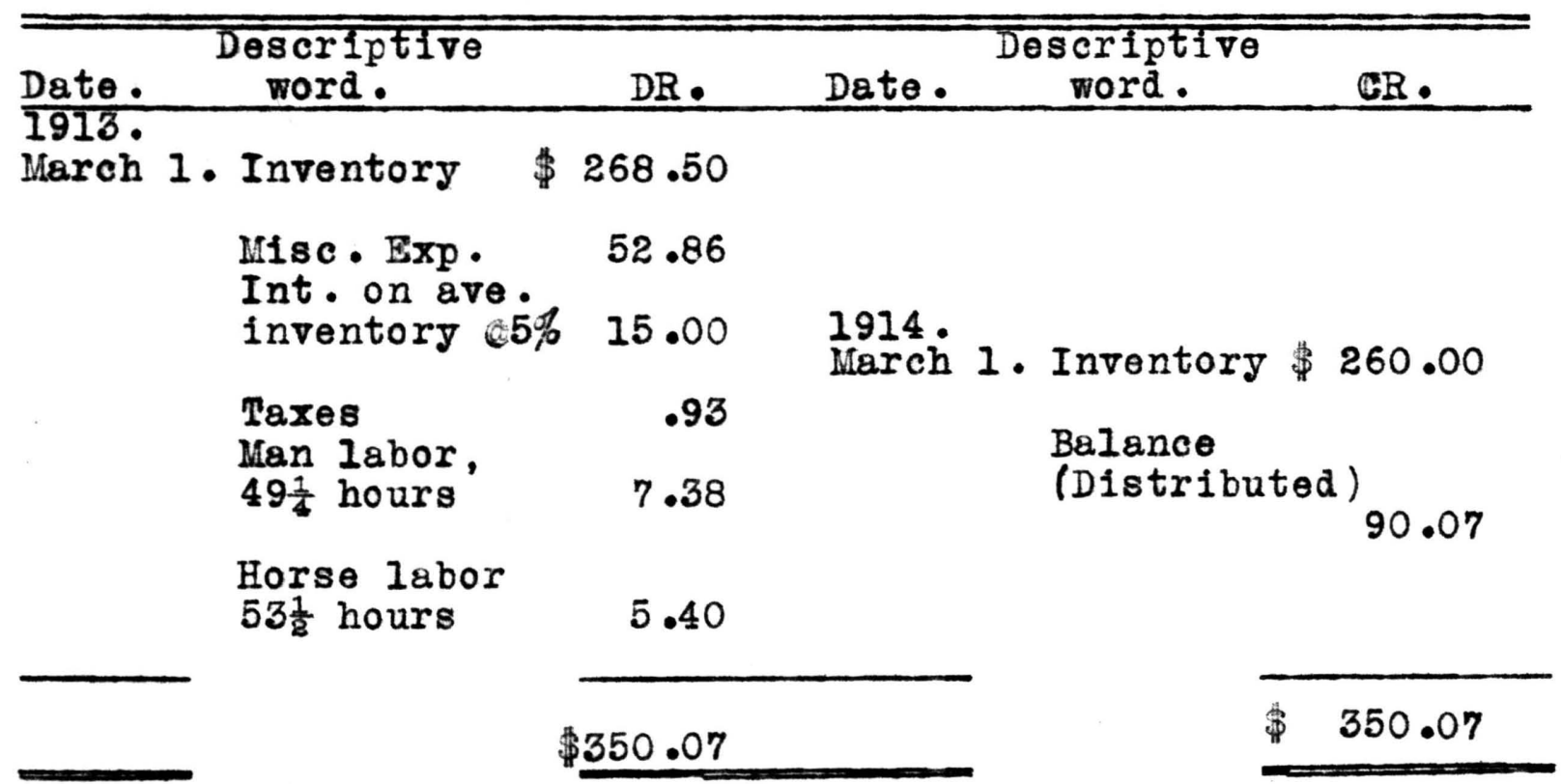


which ordinarly should not be shown in a real-estate account. The reason for the gain here is because of the house rent being credited to real-estate, because 110 cords of wood are valued at $\$ 1.25$ in the inventory which costs only one dollar a cord to have cut, and also because of the addition of repair supplies to the second inventory. An equipment account is shown in table No. IV. This applies specifically to the machinery, tools, carriages and harness and, of course, the productive operations should pay for the upkeep of the machinery. This account should always show a loss. Any expense of money or labor is shown by their respective items, while all depreciations are taken care of in the inventory. If a new machine is bought, this account is charged with it, and in the second inventory the account gets the proper credit after deduction for depreciation. So the balance of the equip ant account is distributed to the other accounts in proportion to the number of horse hours devoted to each. As a rule, it will be found that more horse labor is required with the more expensive machinery somewhat in proportion to their values.

In tables $V$ and $V I$, are given two field accounts, corn and wheat respectively, The corn crop is charged with all labor applied to the field, also with an equipment, seed and fertilizer charge. The field is given credit for the yield and also for 50\% of the fertilizer application, which includes the labor in applying it. Fertilizer and manure charges are made as follows: 50\% to the first crop, 30,6 to 
TABIE NO - $\boldsymbol{V}$.

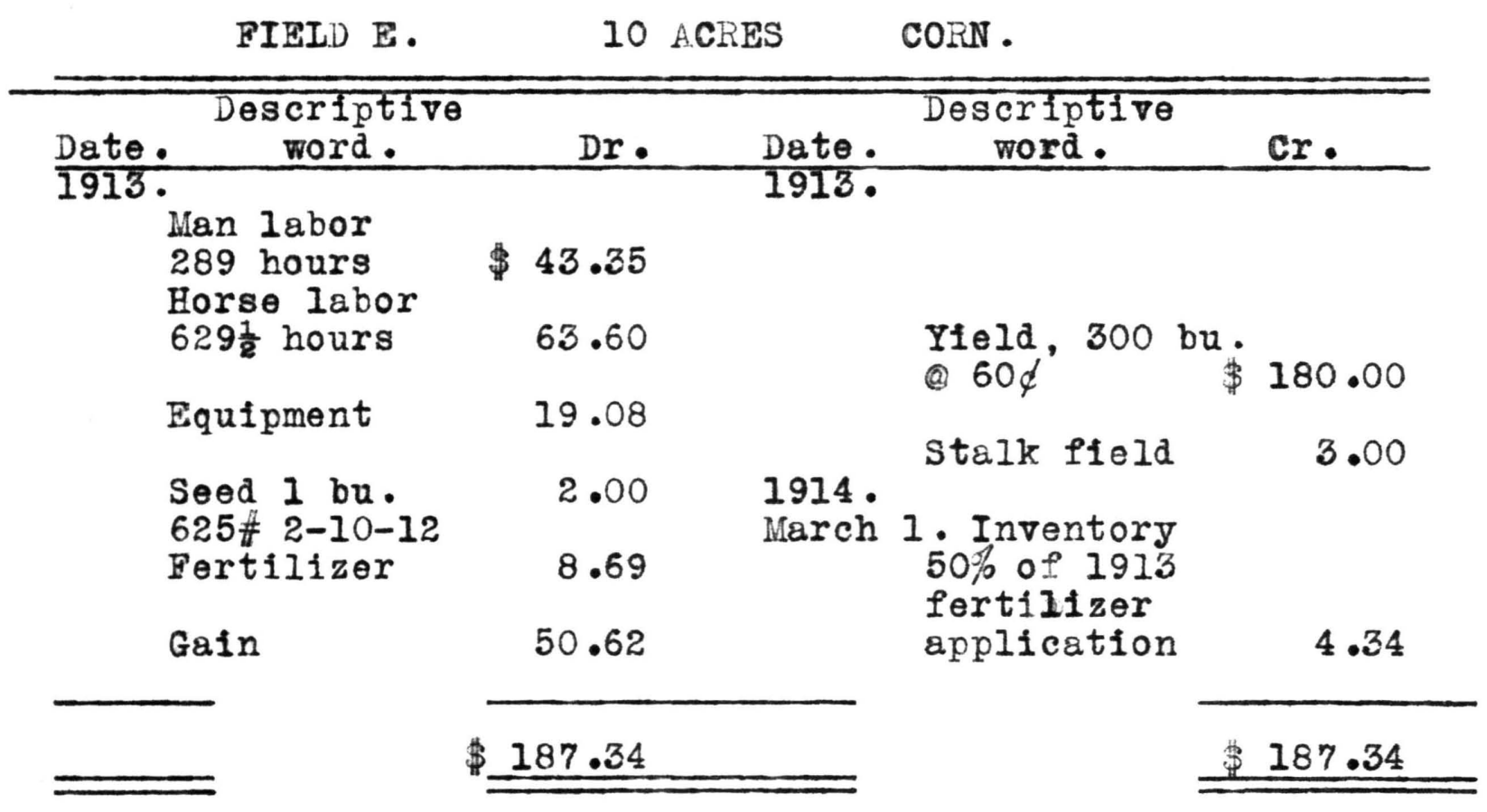

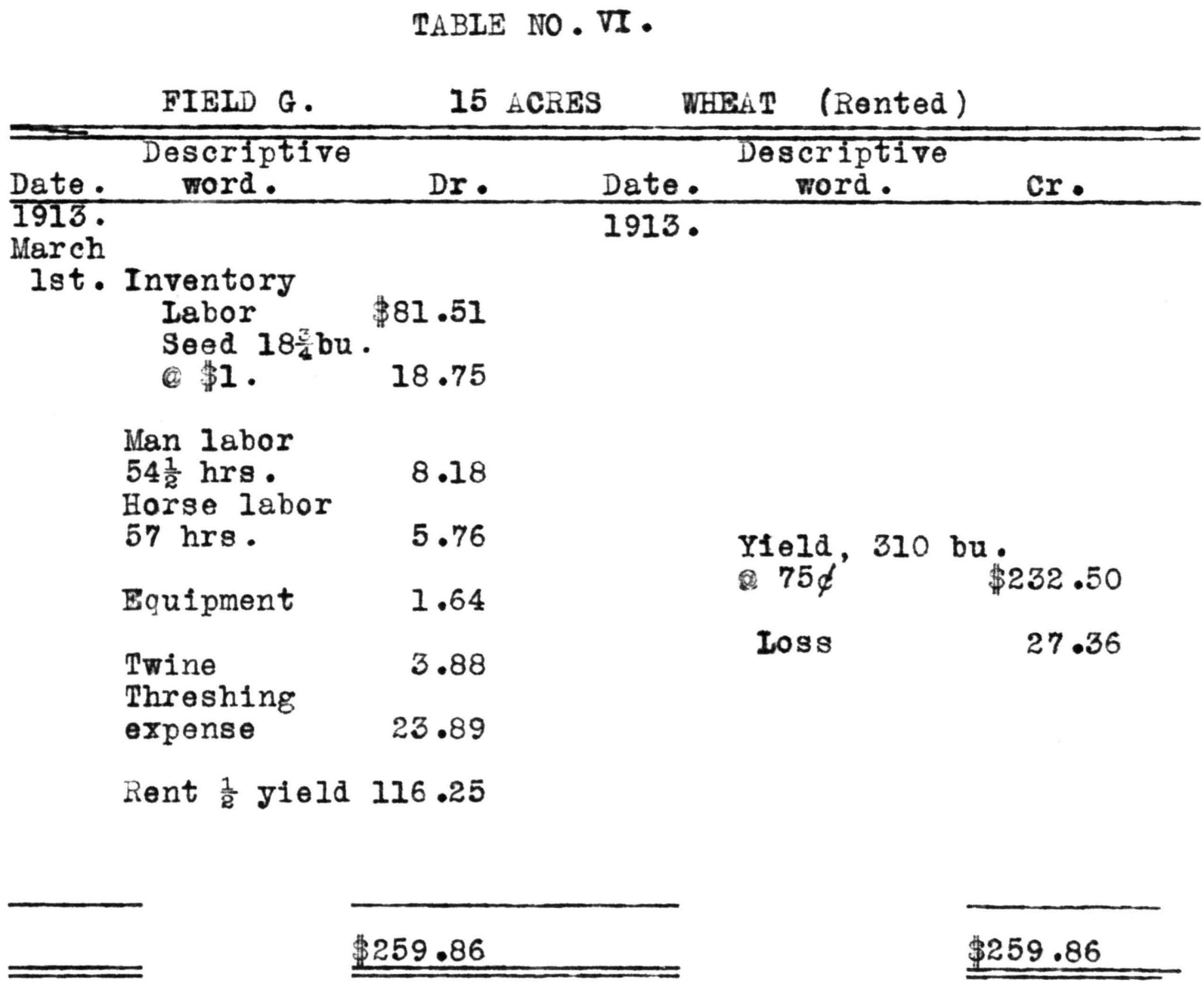


the second crop and $20 \%$ to the third crop. Since a wheat crop extends over a portion of two years it is necessary, in taking the spring inventory, to give an inventory value to the field which will cover labor and seed expense of seeding the wheat crop. The same is true of rye or other similar crop. Fall or winter ploughing also should be charged to a field in the form of an inventory. The wheat field in table VI, shows a loss of $\$ 27.36$, yet the production was over 20 bushels per acre. The secret must lie in the fact that one-half share rent was paid. The value paid in rent amounts to $\$ 7.75$ per acre. This is $\$ 60.00$ land and, at such rent, the owner is receiving $14 \%$ on his investment which is more than he should receive. A point, however, in favor of cash rent for the tenant, and share rent for the owner.

\section{AMNUAI SUMMARY .}

The following pages from 22 to 35 inclusive, include an annual summary which was made out from a diary kept in 1913 by a co-operator. A summary similar to this is compiled for each man who completes a year's record and a copy is sent to him. Instructions are given him regarding portions of the record work that might be kept more complete for the next year. Any particularly favorable or unfavorable operation on the farm that may be brought to light by to the farmev the record is cited ${ }^{\circ}$. He is urged to ask any questions he desires and in this way he is often led to improve conditions 
on his farm.

The first table in this summary is entitled "The Financial statement", and includes both inventories, total debits and credits, and also the loss or gain of each account. The "Iabor cost Summary" which follows gives the total man and horse hours devoted to each account and also the cost of same - Page No .27 headed "Incomes" is probably the most interesting table of this summary, as it shows what the farmer has actually made or lost on his farming operations as a whole. The increase of a man's net worth at the close of the year over what it was at the beginning is what he has gained during the year: or if the second net worth is smaller, he has lost. In this case the gain in net worth is $\$ 89.76$. But in addition to this, he has gotten his living from the farm; his food, clothing and shelter. So in order to find what the farm has really furnished, or to arrive at the farm income, we must $\wedge$ to the $\$ 89.76$, his house-hold expenses, personal expenses, house-rent, and the products raised on the farm that were used in the home. As has already been stated, the farmer makes two Investments; one of capital and another of labor. In order to find the labor income of a farm or what the proprietor himself has received for his labor, $5 \%$ of the average net worth, which pays for capital invested, is subtracted from the farm income. The difference which is $\$ 647.50$, represents his labor income. If there had boen any other unpaid laborers on the farm, such as the farmer's sons, the value of their 
Farm Management Department, University of Missouri.

\section{A N N U A I S U M M A $\mathrm{Y}$}

\section{Farm of}

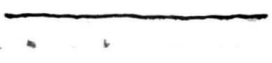

Houstonia, Mo .

Record from

March 1, 1913,

to

March 1, 1914. 
FINANCIAI STATEMENT

\begin{tabular}{|c|c|c|c|c|c|c|}
\hline \multirow[b]{2}{*}{ Resources } & \multicolumn{2}{|c|}{ Inventory } & \multicolumn{2}{|c|}{ Accounts } & \multicolumn{2}{|c|}{ Balance } \\
\hline & 1913 & 1914 & Dr. & Cr. & Los8 & Gain \\
\hline Horses & 550.00 & 510.00 & 303.51 & 343.51 & & \\
\hline Cows & 115.00 & 193.00 & 173.80 & 115.00 & & 19.20 \\
\hline Hogs & 486.00 & 494.00 & 840.55 & 1032.98 & & 200.43 \\
\hline Turkeys & 21.50 & 41.00 & 108.37 & 184 .20 & & 95.33 \\
\hline Ehickens & 50.00 & 170.00 & 281.99 & 165.19 & & 3.20 \\
\hline Foed and $S$ & 1.488 .03 & 289.03 & 1233.09 & 1308.91 & 122.96 & \\
\hline Equipment & 268.50 & 260.00 & 81.57 & 90.07 & & \\
\hline Household & 330.00 & 263.00 & 764.20 & 139.57 & 691.63 & \\
\hline Estate. & 4500.00 & 4981.00 & 637.25 & $331 \cdot 83$ & & 175.58 \\
\hline Tash & 236.80 & 56.47 & $1547 \cdot 74$ & 1728.07 & & \\
\hline Stock & & 30.00 & & & & 30.00 \\
\hline Rec. & & 14.87 & 14.87 & & & \\
\hline Field A & & & 82.38 & 30.00 & 52.38 & \\
\hline Field A2 & & & 35.48 & - & 35.48 & \\
\hline Field B & & & 68.45 & 115.20 & & 46.75 \\
\hline Field & 30.60 & & 22.44 & 72.75 & & 19.71 \\
\hline Field E. & & 4.34 & $136 \cdot 72$ & 183.00 & & 50.62 \\
\hline Field P. & & 11.60 & 11.60 & & & \\
\hline Fleld S. & & 51.85 & 51.85 & & & \\
\hline Field W. & & 6.08 & 7.82 & & 1.74 & \\
\hline Field X. & & & 34.01 & 24.00 & 10.01 & \\
\hline Field z & & 9.26 & 22.75 & & 13.50 & \\
\hline Pield & 100.26 & & 159.60 & 232.50 & 27.36 & \\
\hline Cane Patch & & & 2.49 & & 2.49 & \\
\hline Pasture & & & 120.40 & 101.45 & 18.95 & \\
\hline Personal & & & 161.90 & & 161.90 & \\
\hline Outside & & & 9.14 & 1.15 & 7.99 & \\
\hline
\end{tabular}


FINANCIAI STATEMENT

\begin{tabular}{|c|c|c|c|c|c|c|}
\hline \multirow[b]{2}{*}{ Resources } & \multicolumn{2}{|c|}{ Inventory } & \multicolumn{2}{|c|}{ Accounts } & \multicolumn{2}{|c|}{ Bदियाज्ध } \\
\hline & 1913 & 1914 & Dr. & Cr. & Ioss & Gain \\
\hline Labor & & & 187.55 & $667 \cdot 28$ & & 479.73 \\
\hline Taxes \& In & terest & & 213.75 & 423.63 & & 209.88 \\
\hline General $\mathrm{Fa}$ & & & 73.53 & & 73.53 & \\
\hline Orchard \& & tarden & & 23.76 & 25.90 & & 2.14 \\
\hline $\begin{array}{l}\text { Profit \& I } \\
\text { Total } \\
\text { Resources }\end{array}$ & 7176.69 & $\$ 7385.72$ & 1.25 & & 1.25 & \\
\hline $\begin{array}{r}\text { Bills } \\
\text { Payable }\end{array}$ & 3116.65 & 3235.92 & $117 \cdot 70$ & 215.33 & 21.64 & (error) \\
\hline Net Worth & 4060.04 & 4149.80 & & & & \\
\hline Gain & $89 \cdot 76$ & & & & 89.76 & \\
\hline TOTAI & 4149.80 & 4149.80 & 7531.52 & 7531.52 & 1332.57 & 1332.57 \\
\hline
\end{tabular}


IABOR COST SUMMARY.

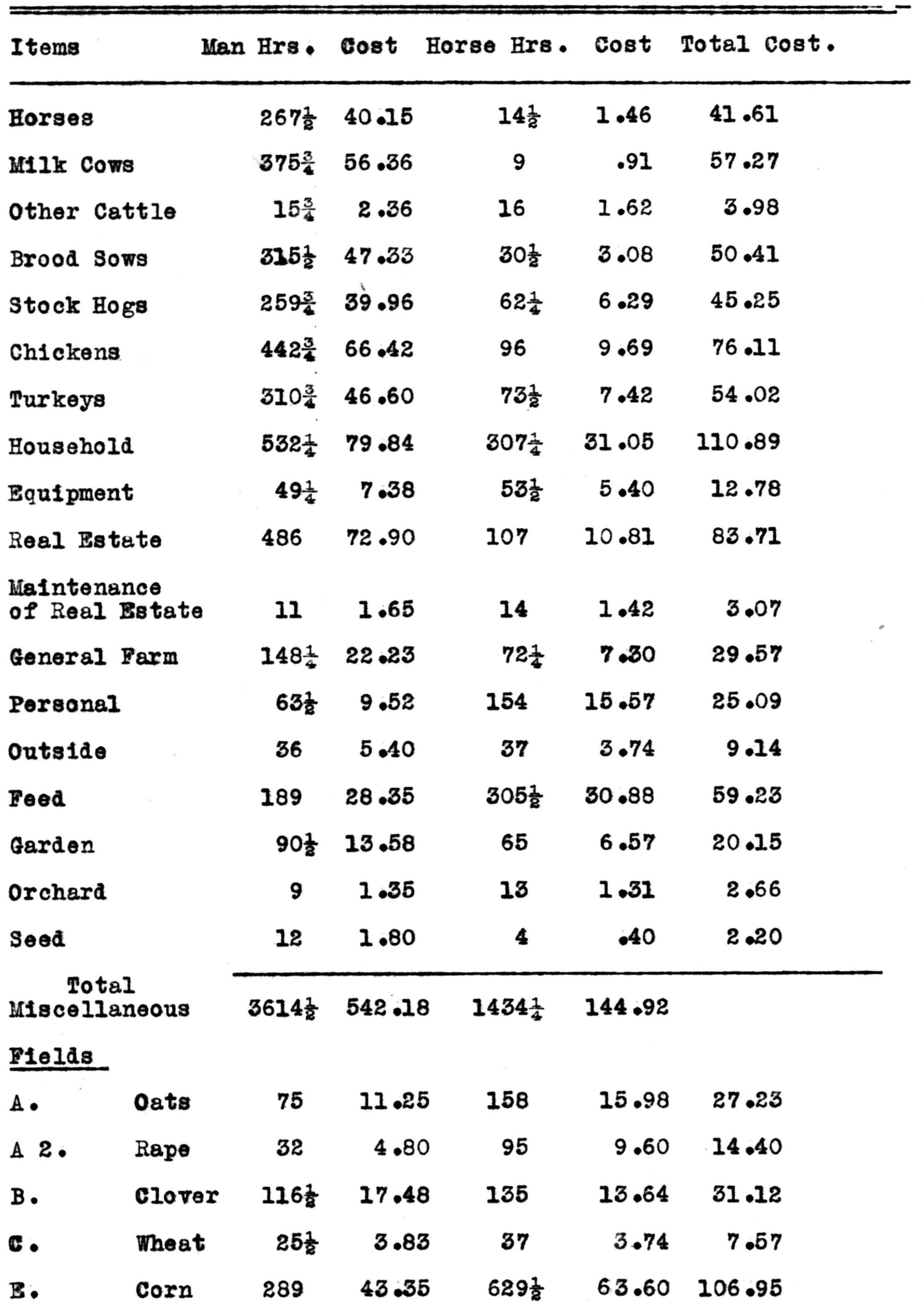


IABOR COST SUMMARY.

Items Man Hrs. Cost. Horse Hrs • Cost. Total cost.

Plelda:

$\begin{array}{llrrrrr}\text { W. Wheat } & 3 \frac{1}{2} & .53 & 12 & 1.21 & 1.74 \\ \text { X. Cowpeas } & 73 \frac{1}{2} & 11.02 & 153 & 15.49 & 26.49 \\ \text { Marshall Field } & 54 \frac{1}{2} & 8.18 & 57 & 5.76 & 13.94 \\ \text { Cane Patch } & 6 \frac{1}{2} & .97 & 15 & 1.52 & 2.49 \\ \text { Z } & \text { Rape } & 3 & .45 & 6 & .60 & 1.05\end{array}$

Supplement, 1914 Crops:

\begin{tabular}{|c|c|c|c|c|c|c|}
\hline P. & $\operatorname{Corn}$ & 24 & 3.60 & 63 & 6.36 & 9.96 \\
\hline s. & $"$ & $95 \frac{1}{2}$ & 14.32 & $274 \frac{1}{2}$ & 27.73 & 42.05 \\
\hline W. & Wheat & 17 & 2.55 & 35 & 3.53 & 6.08 \\
\hline z. & $"$ & $18 \frac{1}{2}$ & 2.77 & 48 & 4.85 & 7.52 \\
\hline otal & Field & 834 & 125.10 & 1718 & 173.59 & \\
\hline RAND & TOTAI & $4448 \frac{1}{2}$ & 667.28 & $3152 \frac{1}{4}$ & $\$ 318.51$ & $985 \cdot 79$ \\
\hline
\end{tabular}

Rates:

$\begin{array}{ll}\text { Man } & 15 \phi \\ \text { Horse } & 10.1 \varnothing\end{array}$




\section{I $N O O M E S$.}

\section{Farm Income.}

Difference in Net Worths

$\$ 89.76$

Household Expenses

228.37

Personal Expenses

132.12

Products used in Home

279.58

House Rent

120.00

Farm Income

849.83

\section{Iabor Income.}

Farm Income

$849 \cdot 83$

Int. on ave. net worth $5 \%$

202.33

Iabor Income

647.50

\section{Interest on Investment.}

Farm Income

$849 \cdot 83$

Value of Proprietor's Iabor $2276 \frac{1}{2}$ hours $\Leftrightarrow 15 \phi$

341.47

Interest received on Investment 508.36

Ave. net worth

$\$ 4046.56$

$508.36+4046.56=12.5 \%$ 
IIVE STOCE ACCOUNTS.

H O R S S .

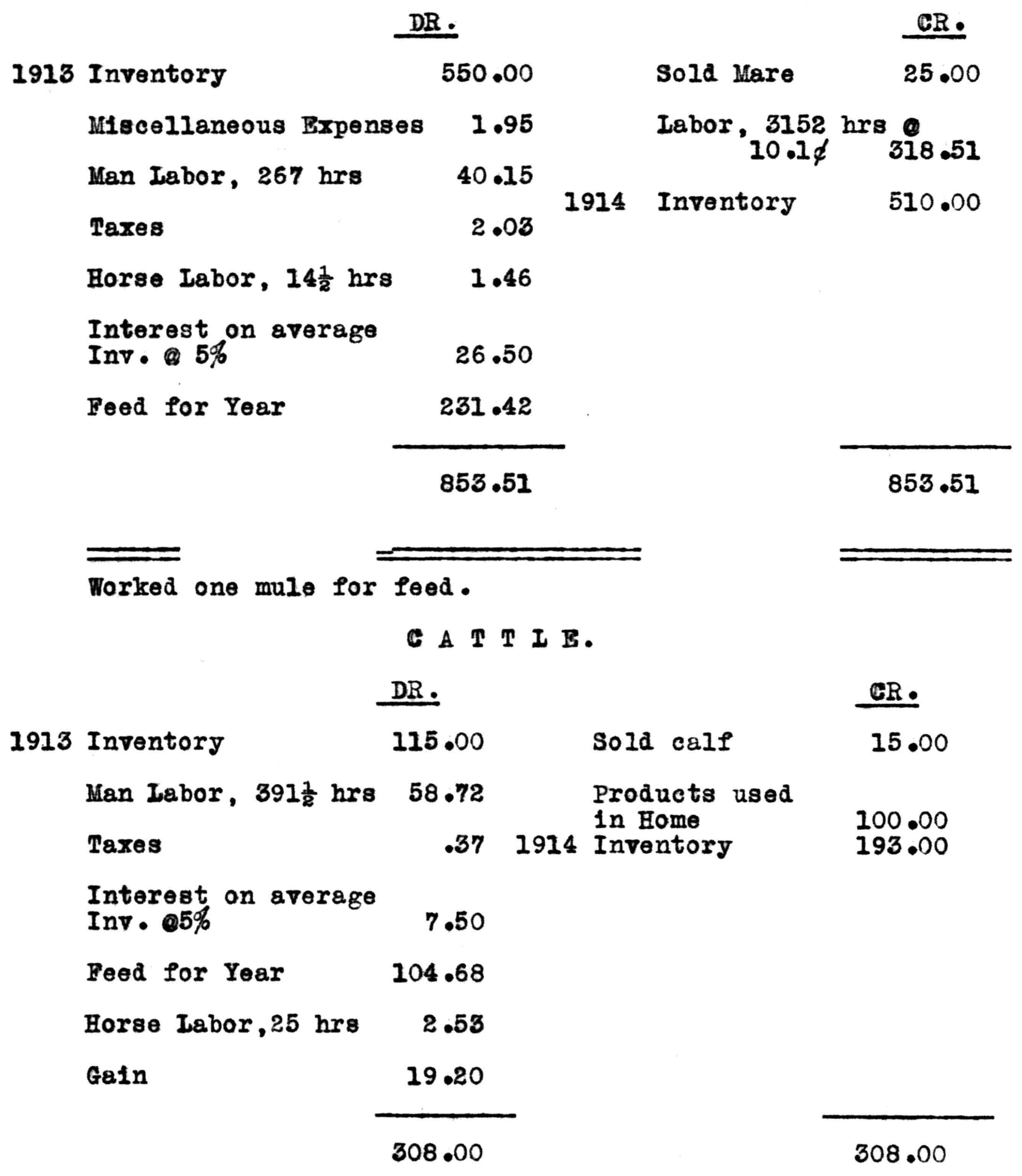




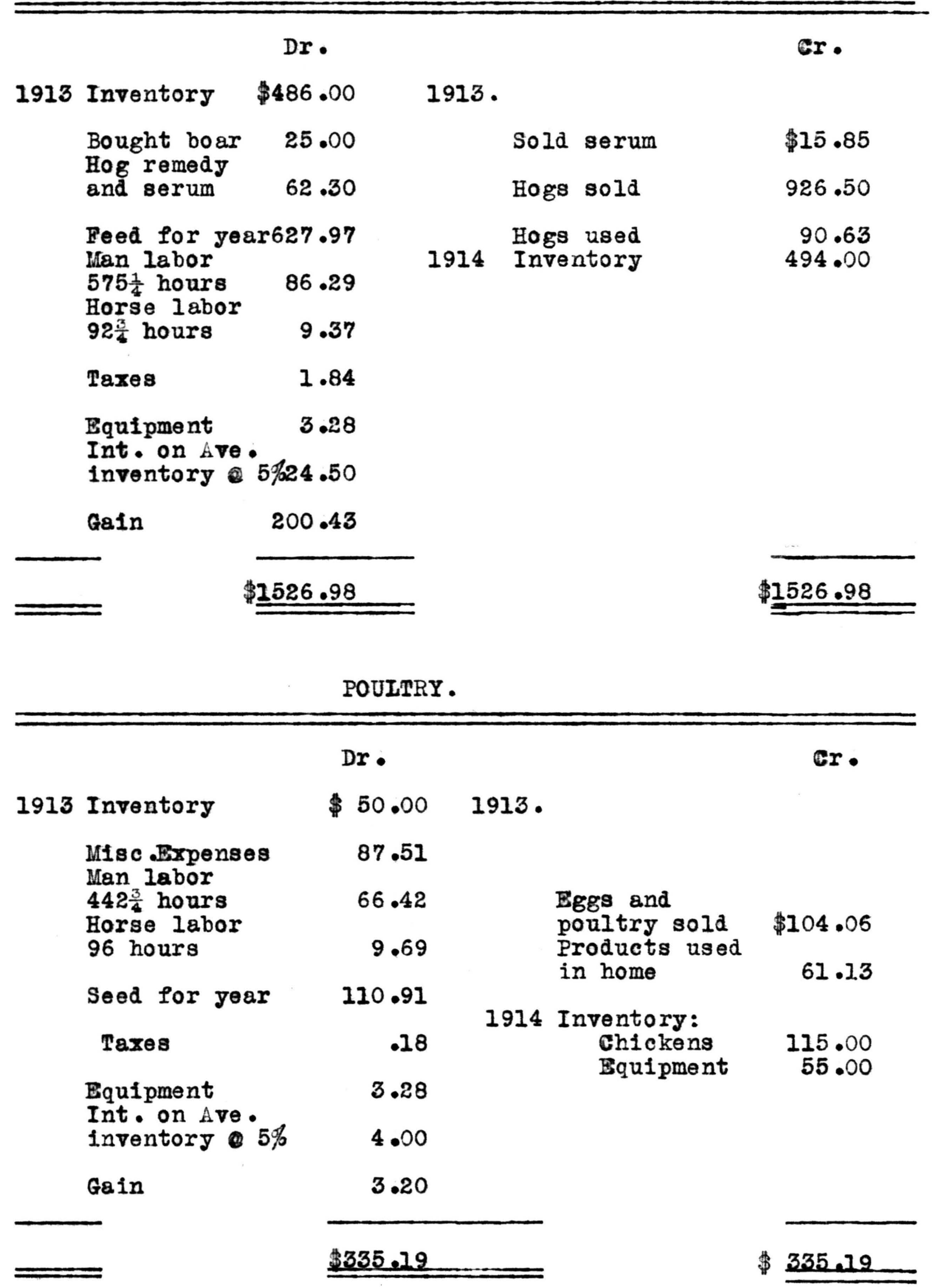


TURKEYS .

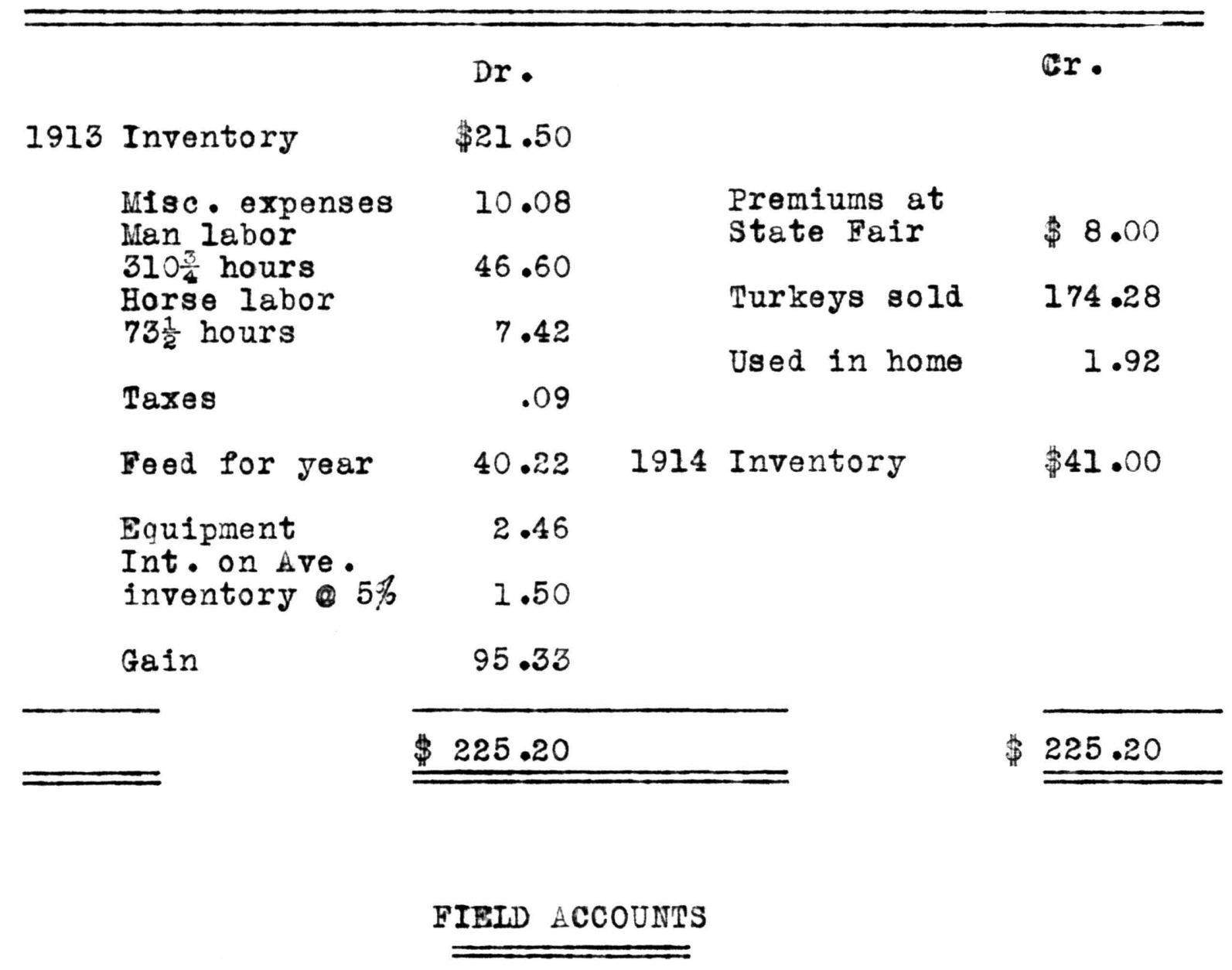

Field A.

10 Acres.

Oats.

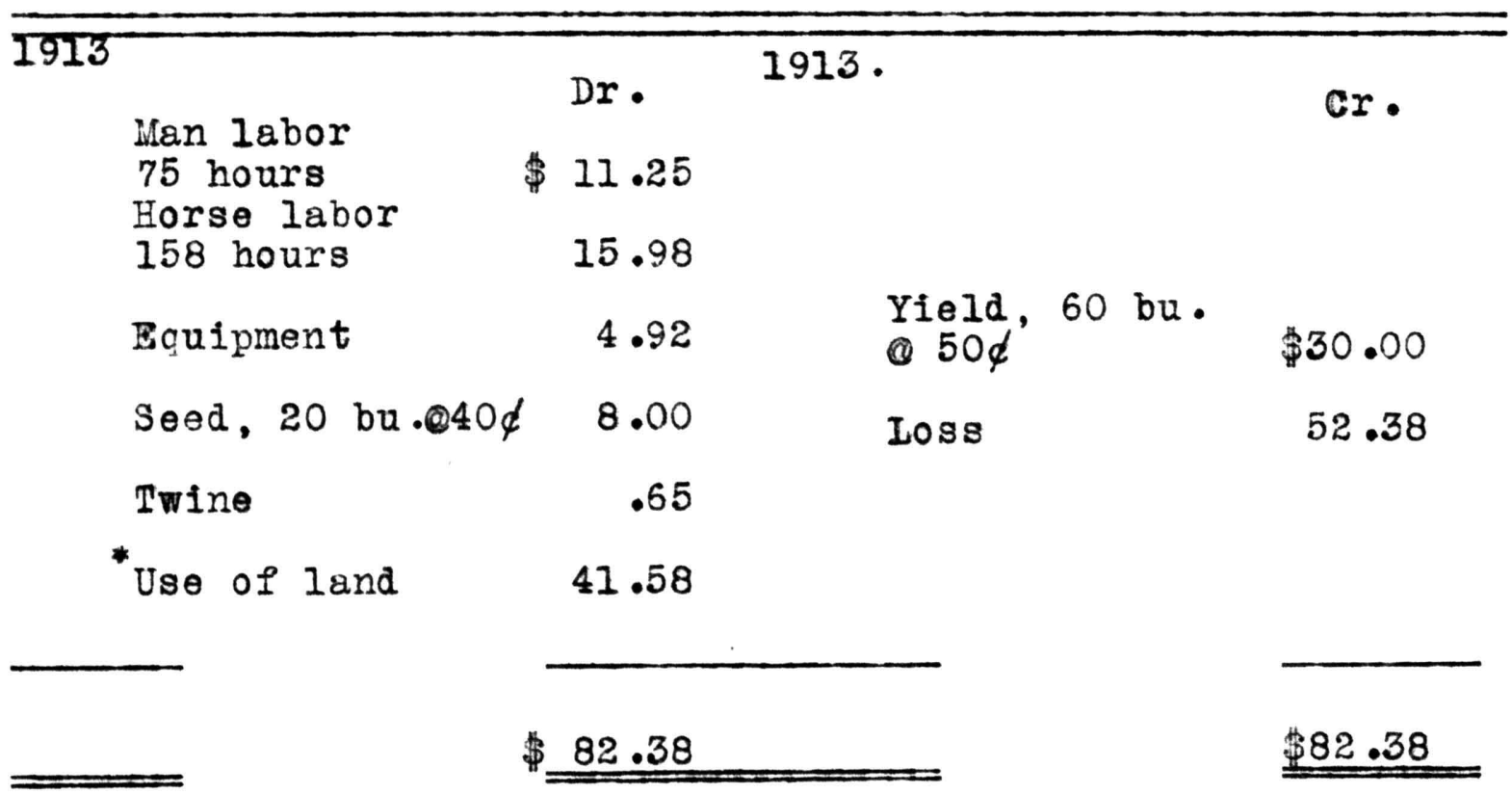

* Use of land includes interest on investment, taxes, ana maintenance of real-estate. 


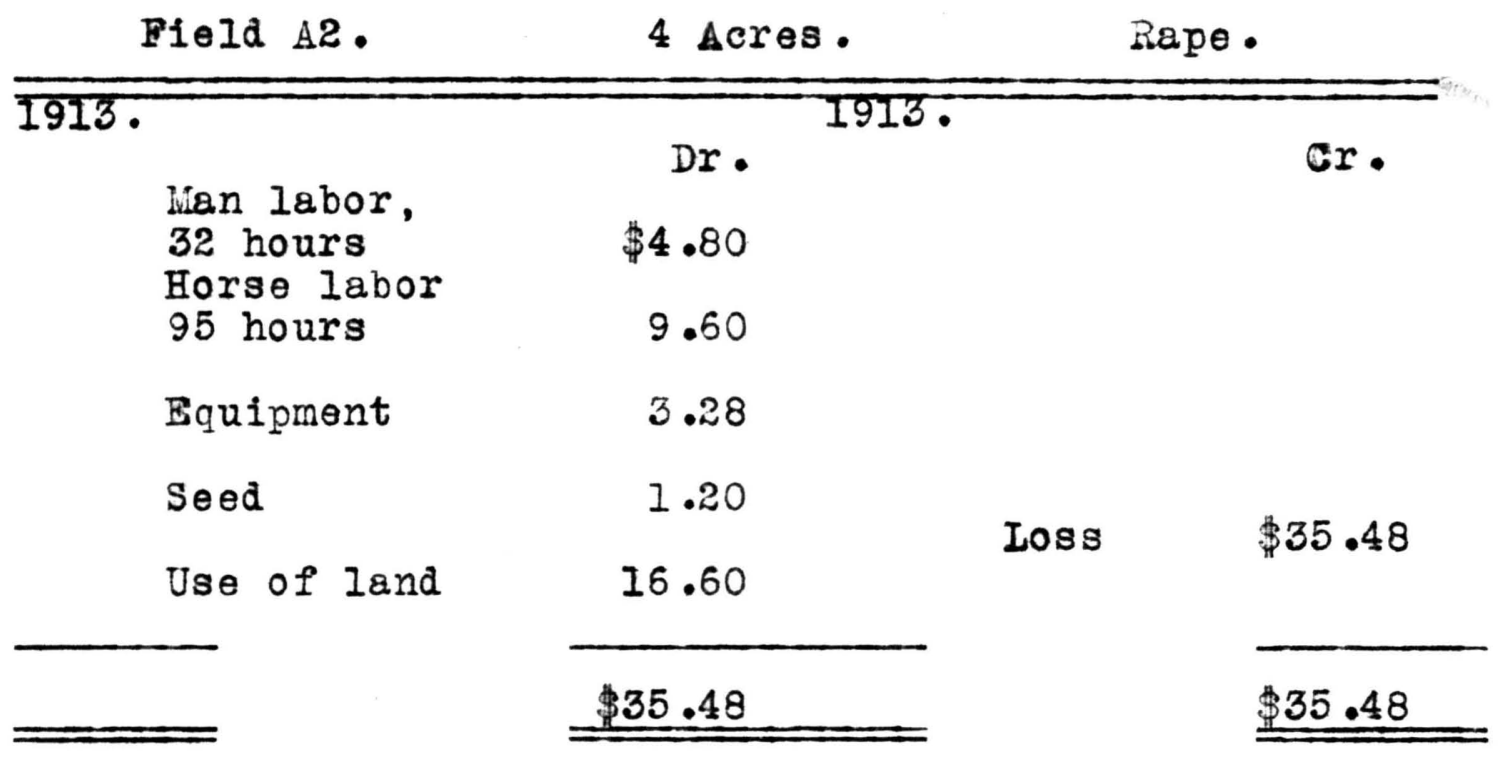

This rape crop was pastured, but the value of it was not kept separate from other pastures as it should have been, so the yield is included in a pasture account which is given later.

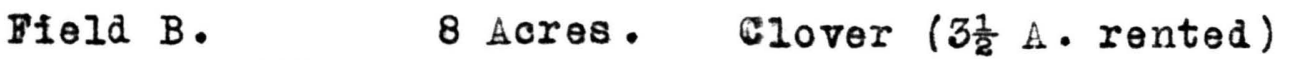

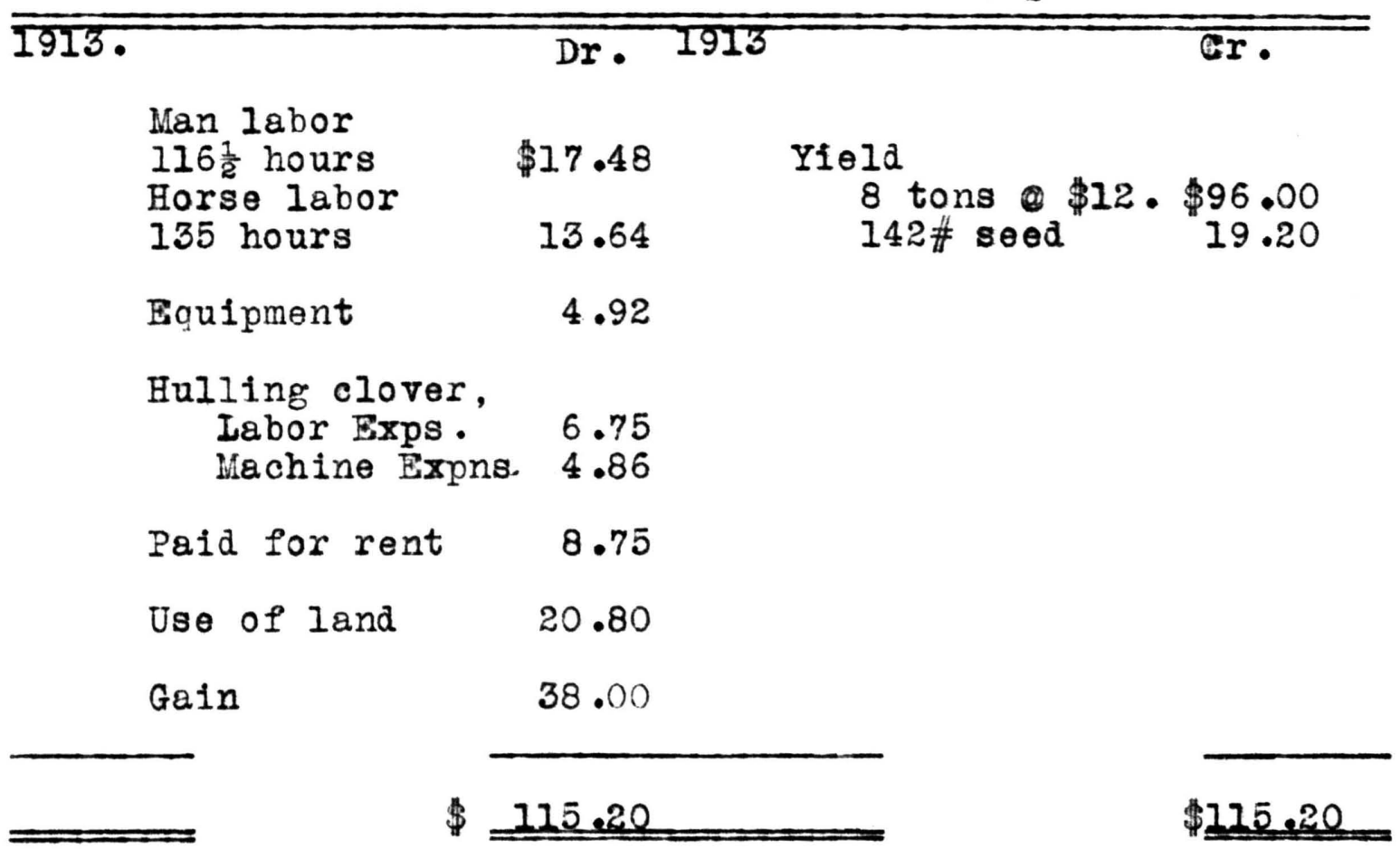




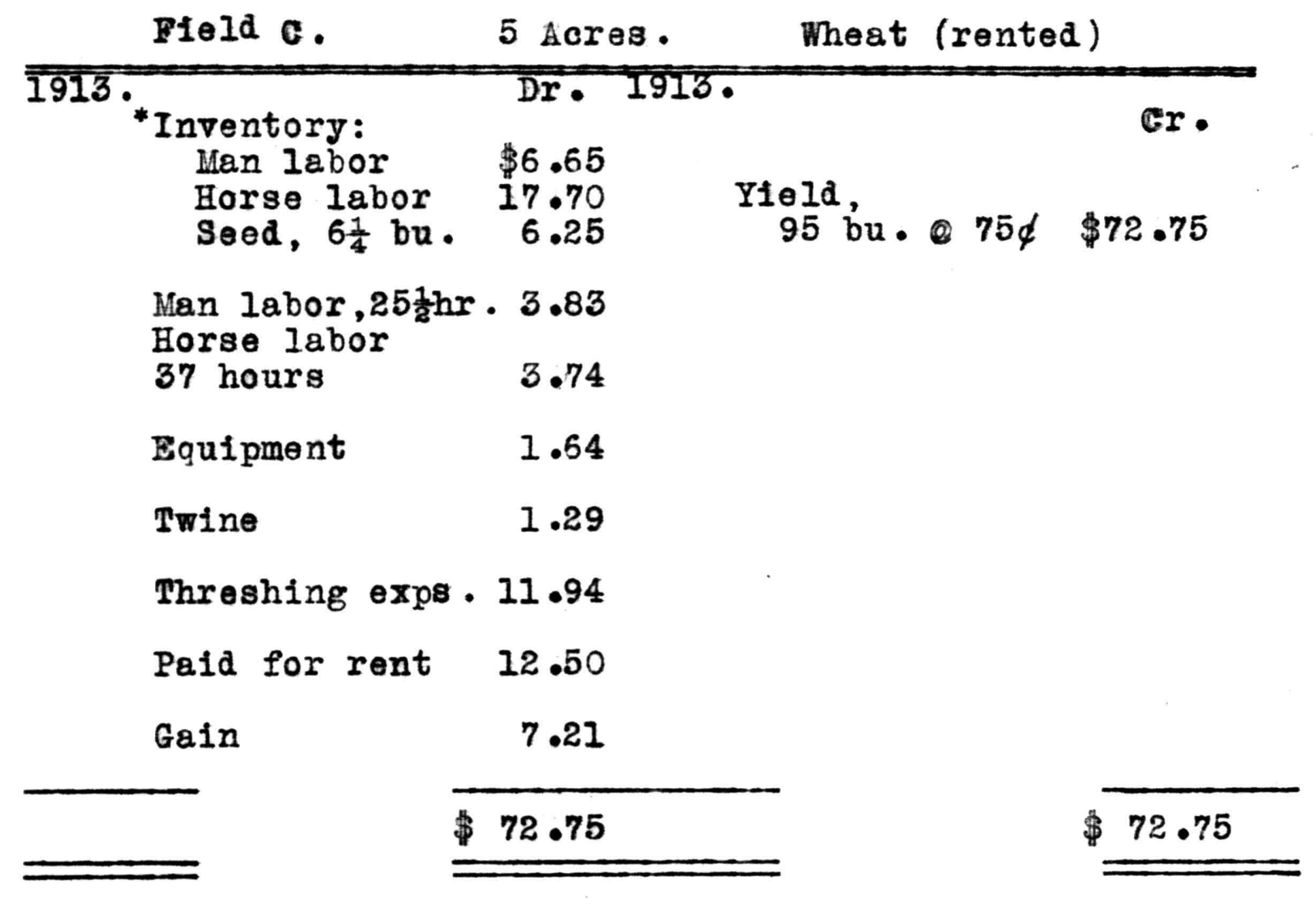

* This inventory includes the value of labor and seed in seeding the crop.

Field E. 10 Acres. Corn (rented)

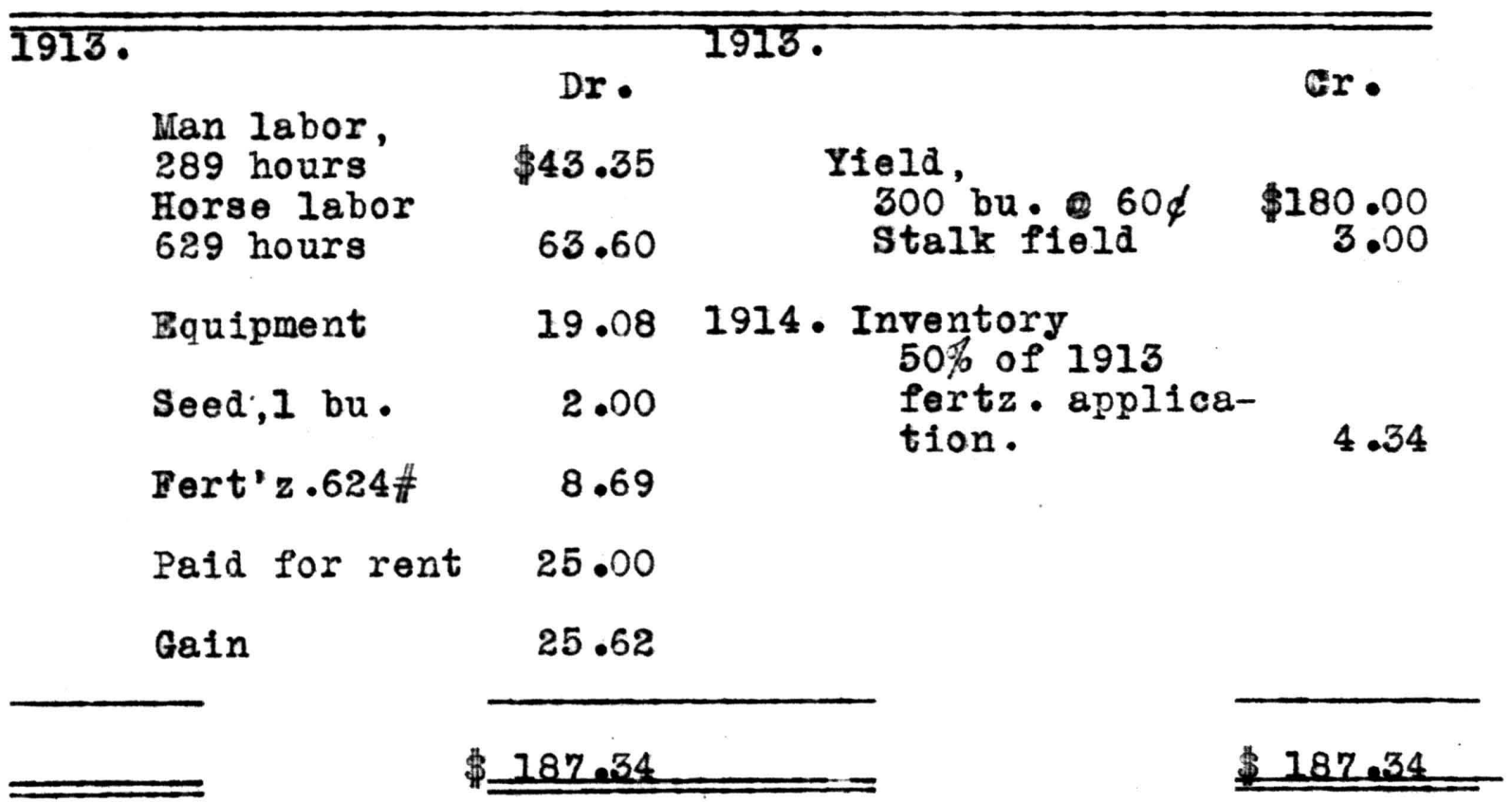


Field $7 . \quad 1 / 2$ Acre.

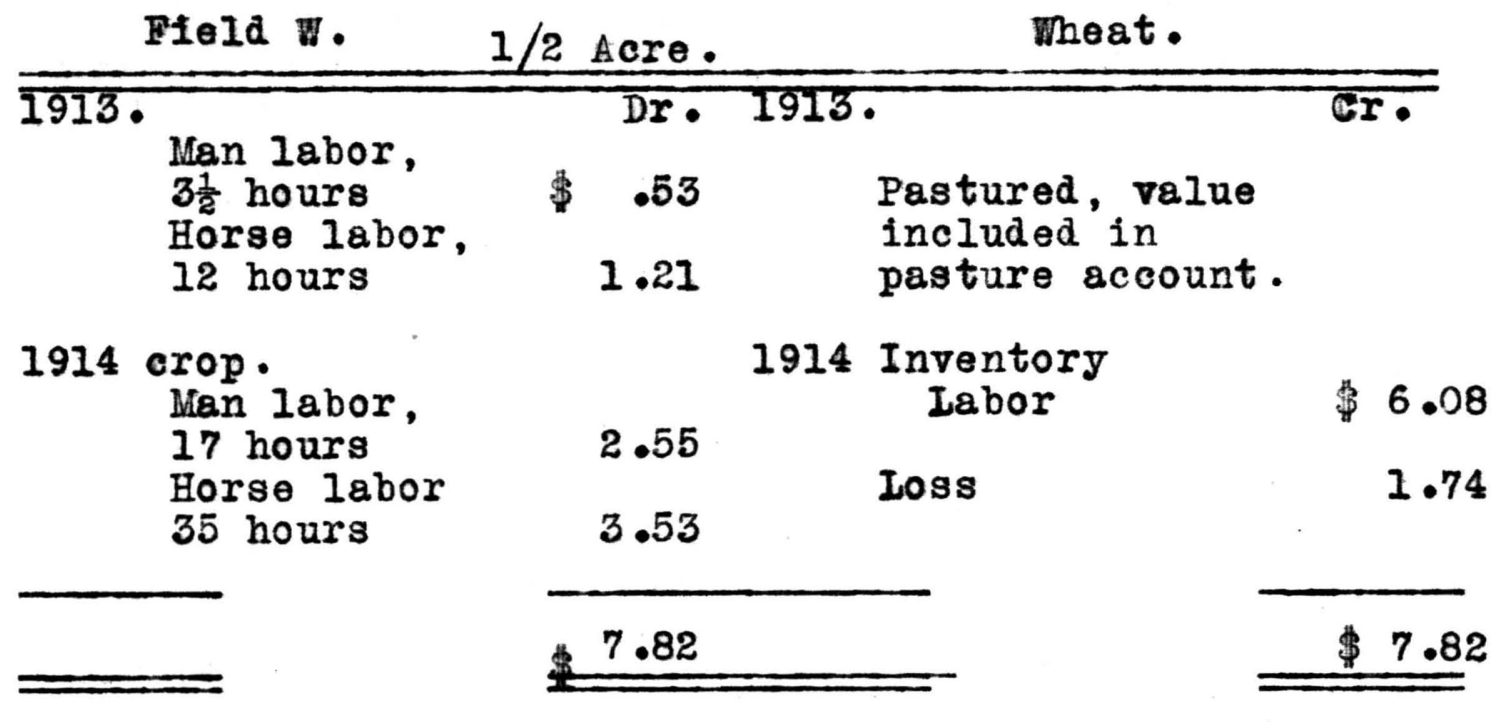

Wheat.

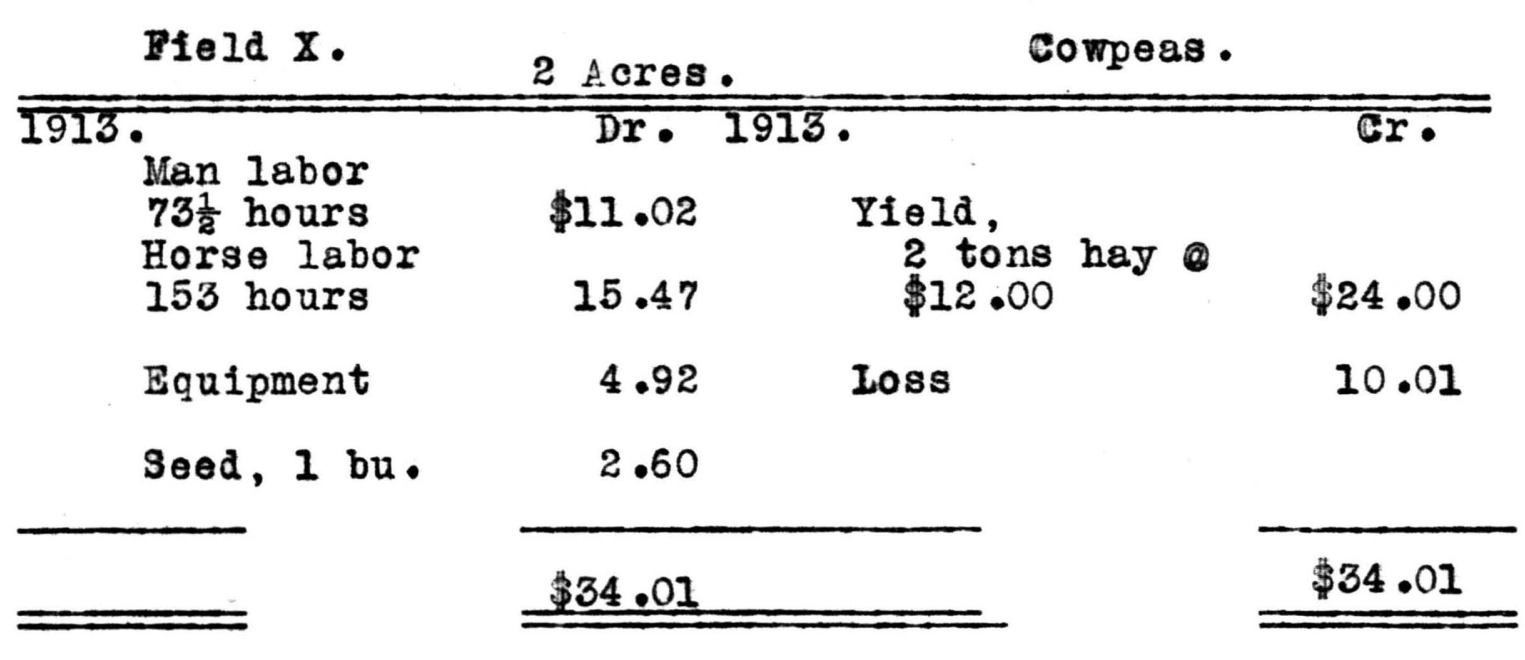

Cane Patch.

\begin{tabular}{|c|c|c|c|}
\hline 1913. & $\overline{\mathrm{Dr}} \cdot$ & 1913. & $\overline{\text { Gr. }}$ \\
\hline $\begin{array}{l}\text { Man labor, } \\
6 \frac{1}{2} \text { hours } \\
\text { Horse labor, } \\
15 \text { hours }\end{array}$ & $\begin{array}{r}\$ .97 \\
1.52\end{array}$ & $\begin{array}{l}\text { No yield reported. } \\
\text { Ioss }\end{array}$ & \$ 2.49 \\
\hline & $\$ 2.49$ & & 事 2.49 \\
\hline
\end{tabular}




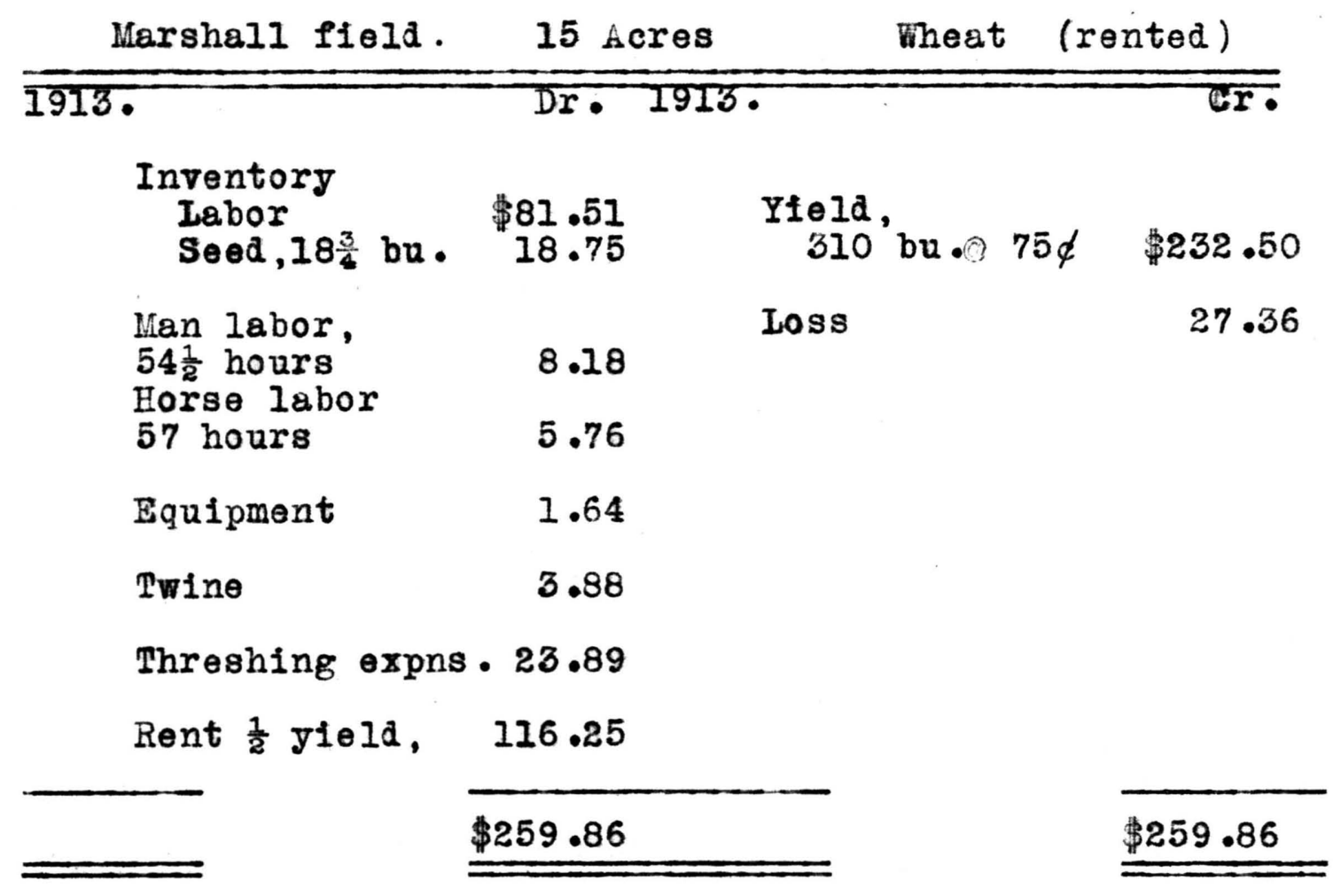

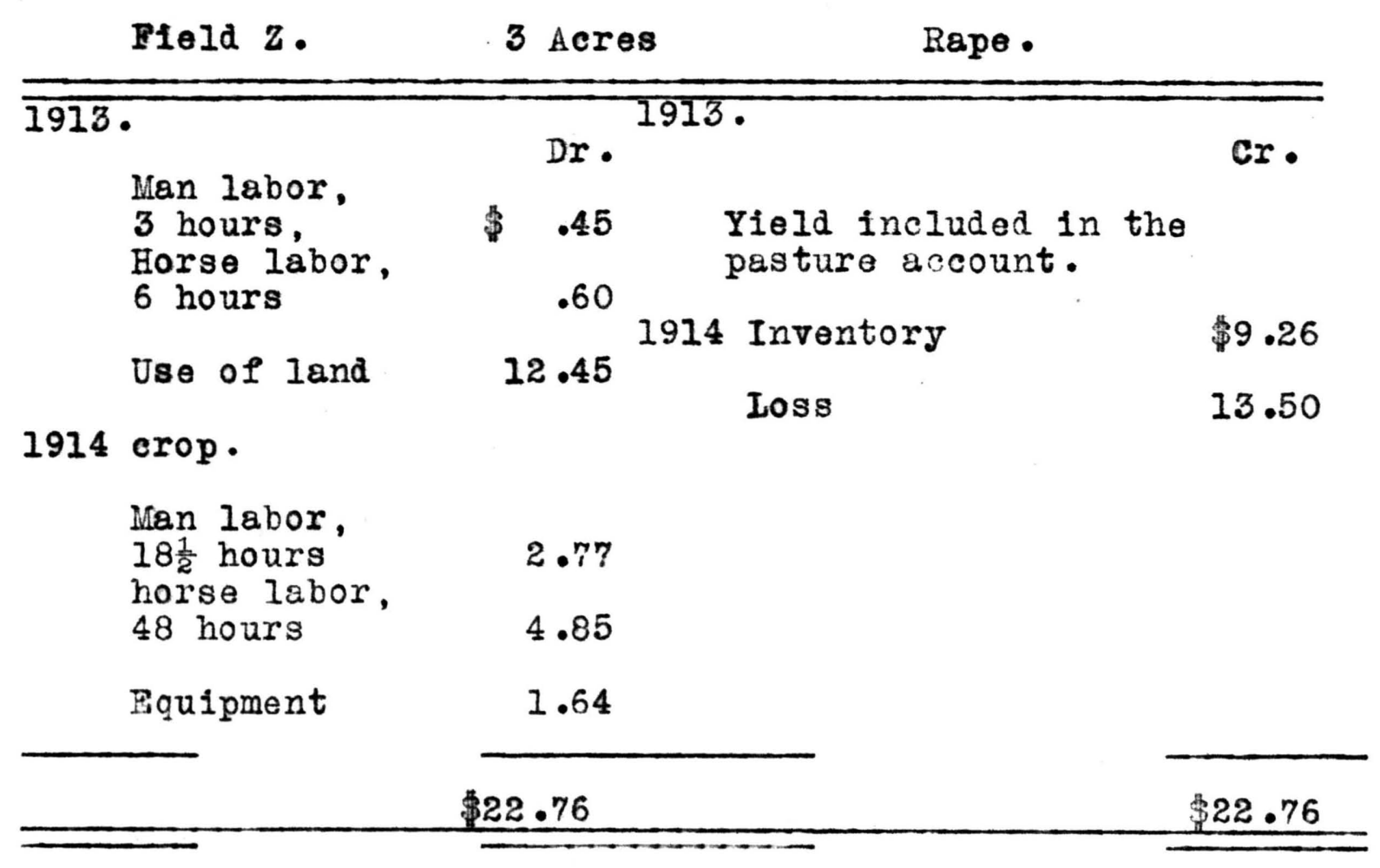


Field P.

15 Acres

Corn, 1914 crop.

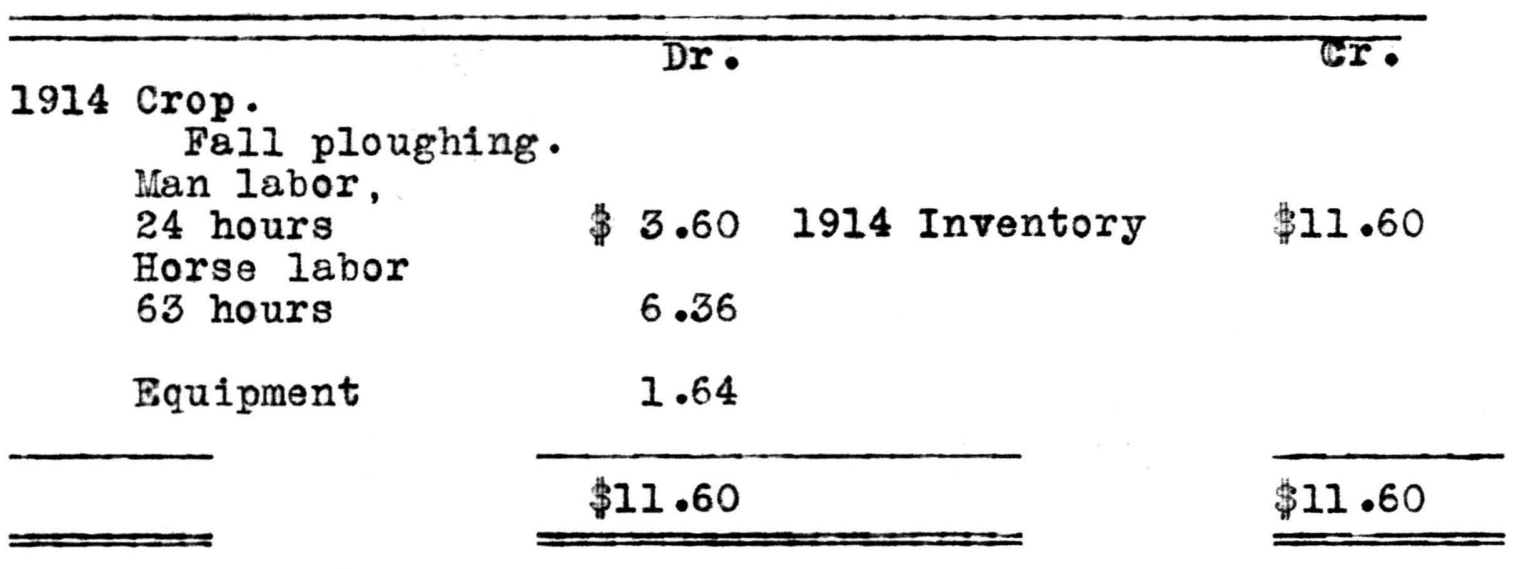

Field s.

35 Acres. Corn, 1914 crop.

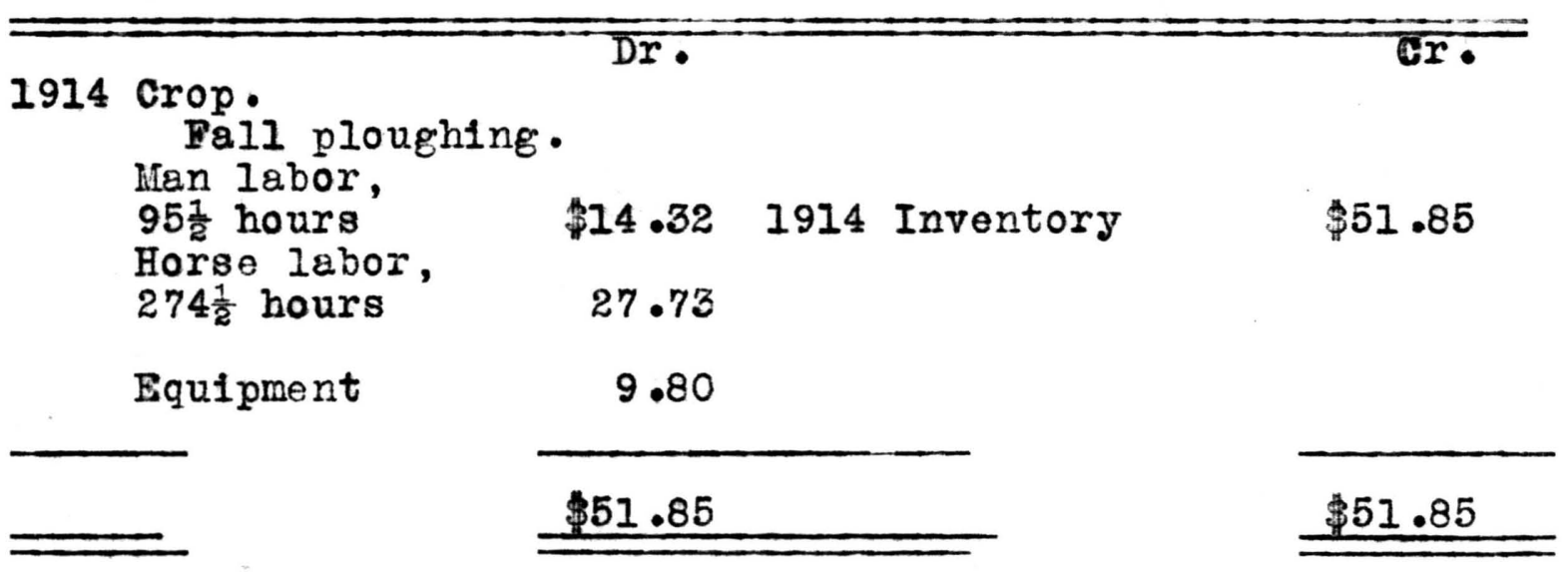

\begin{tabular}{|c|c|c|c|}
\hline$\overline{1913 .}$ & Dr. & & cr. \\
\hline \multirow[t]{3}{*}{ Use of land } & $\$ 120.40$ & $\begin{array}{l}\text { Yield, } \\
\text { Pasture } \\
\text { feeding }\end{array}$ & $\begin{array}{l}\text { value from } \\
\text { record. } \$ 101.45\end{array}$ \\
\hline & & Loss & 18.95 \\
\hline & $\$ 120.40$ & & $\$ 120.40$ \\
\hline
\end{tabular}

* Since no record was kept of the fields in which pasturing was done, a pasture account has been made and given credit for all pasture values. It has been charged with the use of land at one-half the rate the cultivated land was charged. 
labor also would have been subtracted from the farm income, as labor income refers only to the income from the proprietor's labor. Interest is figured here on average net worth instead of the average inventory because, interest on the mortgage has been paid during the year and entered in the farm expenses, hence it must not be considered here. As in securing labor income we first pay for capital invested, so in finding what per-cent one has made on capital invested we must first pay for labor invested, and that which remains, the capital gets credit for producing. In this case the difference is $\$ 508.36$, which, when divided by $\$ 4046.56$, the average net worth, gives $12.5 \%$ made on capital invested.

The remainder of this summary includes the ledger accounts of the different classes of live stock and poultry, also of each field crop. The loss or gain in each case is given and often a note is inserted explaining the probable reason for a loss or an unusual gain.

\section{MISCELIANGOUS TABLES .}

Following will be given a number of tables and curves bringing out many points of interest. Each will be referred to and briefly described.

Tables No. VII and VIII deal specifically with the length of the work day on the farm. The former table shows results from eight farms, and the average length of the day 
TABIE NO. VII.

Number Man Hours Worked per Week Day per Farm.

\begin{tabular}{lccc}
\hline $\begin{array}{c}\text { Farm } \\
\text { No. }\end{array}$ & $\begin{array}{l}\text { Total } \\
\text { hours }\end{array}$ & $\begin{array}{c}\text { Average } \\
\text { No. men }\end{array}$ & $\begin{array}{c}\text { Average hours } \\
\text { per week dar. }\end{array}$ \\
\hline 1. & 5022.5 & 1.84 & 9.5 \\
1 A. & 4098.0 & 1.44 & 9.1 \\
2. & 2628.0 & .98 & 9.3 \\
2A. & 2923.0 & 1.03 & 9.1 \\
3. & 10002.0 & 3.36 & 9.5 \\
6. & 4108.7 & 1.33 & 9.9 \\
8. & 5021.5 & 1.73 & 9.3 \\
9. & 4332.2 & 1.36 & 10.2 \\
\hline Average & 811 farms & 9.5 \\
\hline
\end{tabular}


TABIE NO. VIII.

Number Man Hours per Week Day per Month.

8 Farms .

\begin{tabular}{|c|c|c|c|c|}
\hline Month & $\begin{array}{l}\text { Total } \\
\text { hours }\end{array}$ & $\begin{array}{c}\text { Number } \\
\text { men }\end{array}$ & $\begin{array}{l}\text { No ohrs } \\
\text { per man }\end{array}$ & $\begin{array}{l}\text { Hro.per man } \\
\text { per Wk.day }\end{array}$ \\
\hline March & $2109 \cdot 7$ & 10.65 & 198. & 7.6 \\
\hline April & 3476.7 & 13.50 & $257 \bullet$ & 9.9 \\
\hline May & 4002 & 15.10 & 265 . & 9.8 \\
\hline June & 4053.7 & 15.78 & 257 . & 10.3 \\
\hline July & 4213.2 & 15.45 & 273 & 10.1 \\
\hline Aug. & 3739.5 & 14.73 & 254 . & 9.4 \\
\hline Sept. & 3205 . & 12.65 & 253 . & 10.1 \\
\hline oct. & 3157 . & 13.06 & 242 . & 8.9 \\
\hline Nor. & 2896 . & 11.63 & 249 . & 9.6 \\
\hline Dec. & 2789.7 & 11.41 & 244 . & 9.0 \\
\hline Jan. & 2307.5 & 10.08 & 229 . & 8.8 \\
\hline Feb. & 2085.7 & 10.19 & 205 . & 8.5 \\
\hline $1 \mathrm{~A}$ & $\begin{array}{l}\text { (age } \\
\text { Farms) }\end{array}$ & 12.8 & & 9.5 \\
\hline
\end{tabular}


is 9.5 hours. Notice how uniformily the length of day per farm runs. With one exception the length of day ranges between 9 and 10 hours. The results of four farms shown in some previous calculations gives the length of an average work day at 9.9 hours!. Two of the farms from which these figures were secured were dairy farms, while none of these eight farms are devoted to dairying. It is a woll known fact which records prove that the dairyman puts in longer hours per day than the general farmer, so this will account for the difference in our figures.

Table No. VIII, gives the figures from the same eight farms tabulated per month. It will be noticed that the shortest days are in March and the longest in June. April and May are the months of preparing seed beds and planting. The length of day is practically the same in these months. Horses do their longest day's work in May, as table X will show. June is a month of cultivation, hence relative more man labor is required. The labor in July is held up mainly because of a good deal of outside work and permanent improvements done on two or three of the farms. August is always a fairly light month for farm work as the records show. For these farms, however, the labor distribution for the year is not so bad.

Tables IX and $X$ show the length of work day per horse in the same manner that tables VII and VIII dealt with man labor. The lowest number of hours per work day for any farm is 1.8, while the longest work days are recorded on farm

1. Thesis on Iabor Distribution, 1912 - by O.R. Johnson. 
TABIE NO IX.

Number Horse Hours Worked per Week Day per Farm.

\begin{tabular}{|c|c|c|c|}
\hline $\begin{array}{l}\text { Farm } \\
\text { NO. }\end{array}$ & $\begin{array}{l}\text { Total } \\
\text { hours }\end{array}$ & $\begin{array}{r}\text { Ave - Ho - } \\
\text { horses. }\end{array}$ & $\begin{array}{l}\text { Ave hrs. } \\
\text { per } \mathrm{Wk} \text {. day. }\end{array}$ \\
\hline 1. & 4753 & 6.08 & $2 \cdot 7$ \\
\hline $1 \mathrm{~A}$ & 3110.2 & 5.58 & 1.8 \\
\hline 2 . & 3334 & 2.04 & 5.7 \\
\hline 2A & $2962 \cdot 7$ & 3.05 & 3.1 \\
\hline 3. & 11552 • & 8.17 & 4.5 \\
\hline 4. & 4970.5 & 4.79 & 3.3 \\
\hline 5 & $8501 \cdot 2$ & 6.92 & $3.9^{2}$ \\
\hline 6. & 5403 & 7.00 & 2.5 \\
\hline 7 & 3226 • & 4.00 & 2.6 \\
\hline 8. & 4260 & 4.02 & 3.4 \\
\hline \multirow[t]{2}{*}{9.} & 3837 & 4.11 & 3.0 \\
\hline & $\theta$ & Farm & $3 \cdot 26$ \\
\hline
\end{tabular}


TABLE NO. $X$.

Number Horse Hours per Wook Day per Month.

11 Farms

\begin{tabular}{|c|c|c|c|c|}
\hline Month & $\begin{array}{l}\text { Total } \\
\text { hours }\end{array}$ & $\begin{array}{l}\text { No } \\
\text { horses }\end{array}$ & $\begin{array}{l}\text { Hours } \\
\text { per horse }\end{array}$ & $\begin{array}{l}\text { Hrs per horse } \\
\text { per wi. day }\end{array}$ \\
\hline March & 2284.5 & 51 & 45. & 1.7 \\
\hline April & 6073 & 59.3 & 102 . & 3.9 \\
\hline May & 8952.5 & 57.2 & 157. & 5.7 \\
\hline June & 6600 & 55. & 119. & 4.8 \\
\hline July & 6267.2 & 55.8 & 112 . & 4 ॰2 \\
\hline Aug. & $5912 \bullet 7$ & 57. & 104 • & 3.8 \\
\hline Sept. & 4634.2 & 54 . & 85. & 3.4 \\
\hline oct. & 4780.2 & 56.5 & 84. & 3.1 \\
\hline Nov. & $3330 \cdot 2$ & 54 . & 62. & 2.4 \\
\hline Dec. & 2817.2 & 52.6 & 54. & $2 \cdot 0$ \\
\hline Jan. & $2078 \cdot 7$ & 52.7 & 39 . & 1.5 \\
\hline Feb & 2261.7 & 51.6 & 44 . & 1.8 \\
\hline 1 & $\begin{array}{l}\text { ge } \\
\text { Ferms }\end{array}$ & 55. & & 3.26 \\
\hline
\end{tabular}


No. 2, with 5.7 hours. The average of 3.26 hours is indeed small. This shows that the average work horse works less than one-third of his time, allowing 10 hour days. Not only is a small part of the horse power on the farm being utilized, but what is, is very unevenly distributed throughout the year. In the months of January, February and March the length of day worked is less than two hours, while the feed cost is almost as high as in the heavy working season. If at all possible, some system should be practiced that would require a greater use of the horse power that is at present going to waste. Plate $V$ shows in graph the length of a man and horse work day per month, while plate VI shows the same thing per farm. Plate VI shows the average length of day worked for both horse and man per farm. It is enteresting to note how uniformily the length of days men work run, and how unevenly those of horses are. This only goes to prove further, the inefficiency with which horse labor is handled.

Before giving some tables that deal with the cost of keep of farm animals, it will be advisable to state the rate of figuring the cost of labor and feed. Man labor is figured at $14 \phi$ per hour, and horse labor at $9 \phi$, except in the table which deals with work horses, and here horse labor has been figured at what it actually costs on the different farms. Feed was figured as follows: corn (3) $60 \phi$ per bu., oats @ $40 \not$ per bu., hay (12 \$12.00 per ton, straw (34.00 per ton, shredded fodder (\$7.00 per ton, shocked fodder@15\&per shock, sheaf oats (2) $2 \frac{1}{2} \phi$ per bundle, pasture values for horses and 


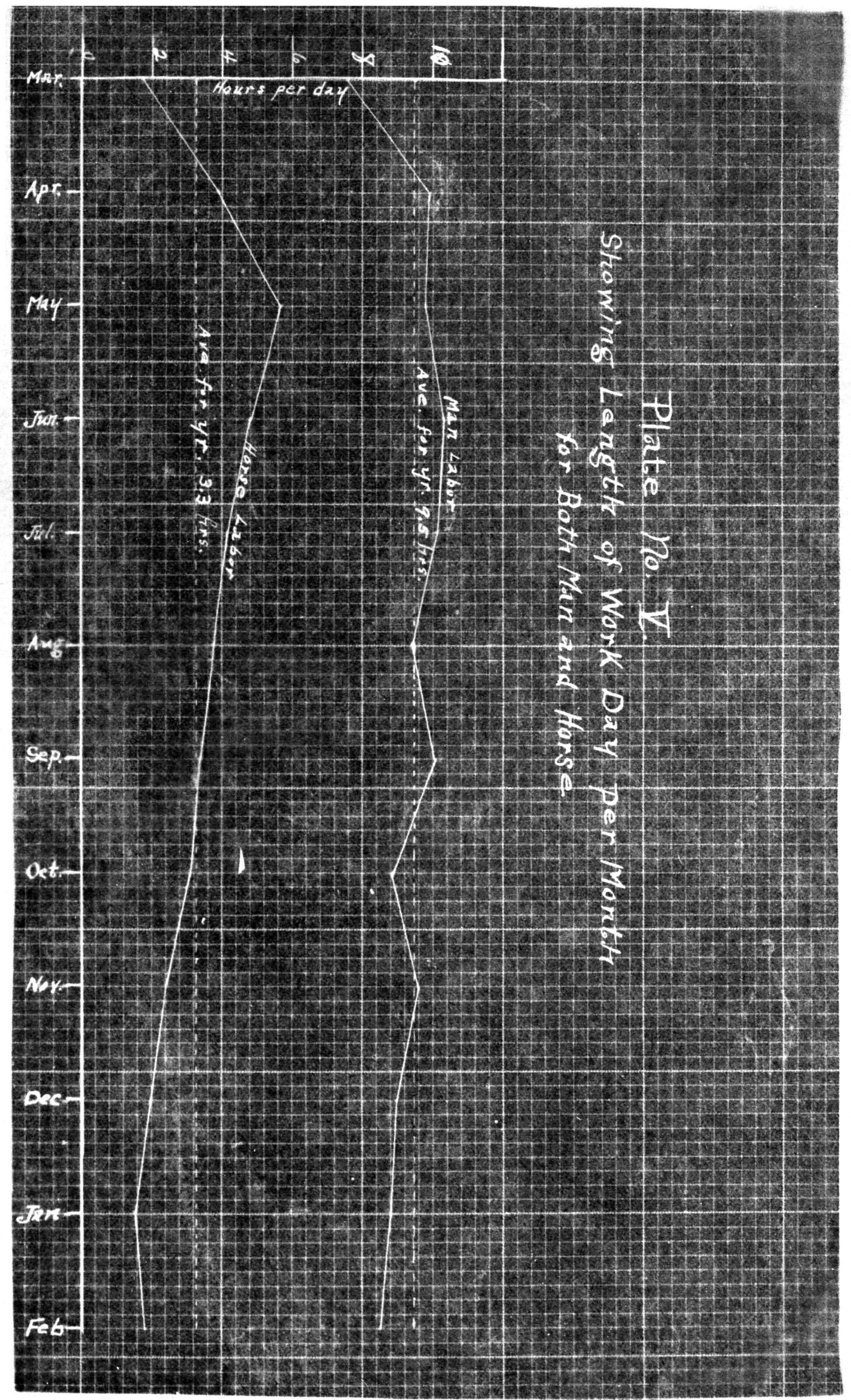




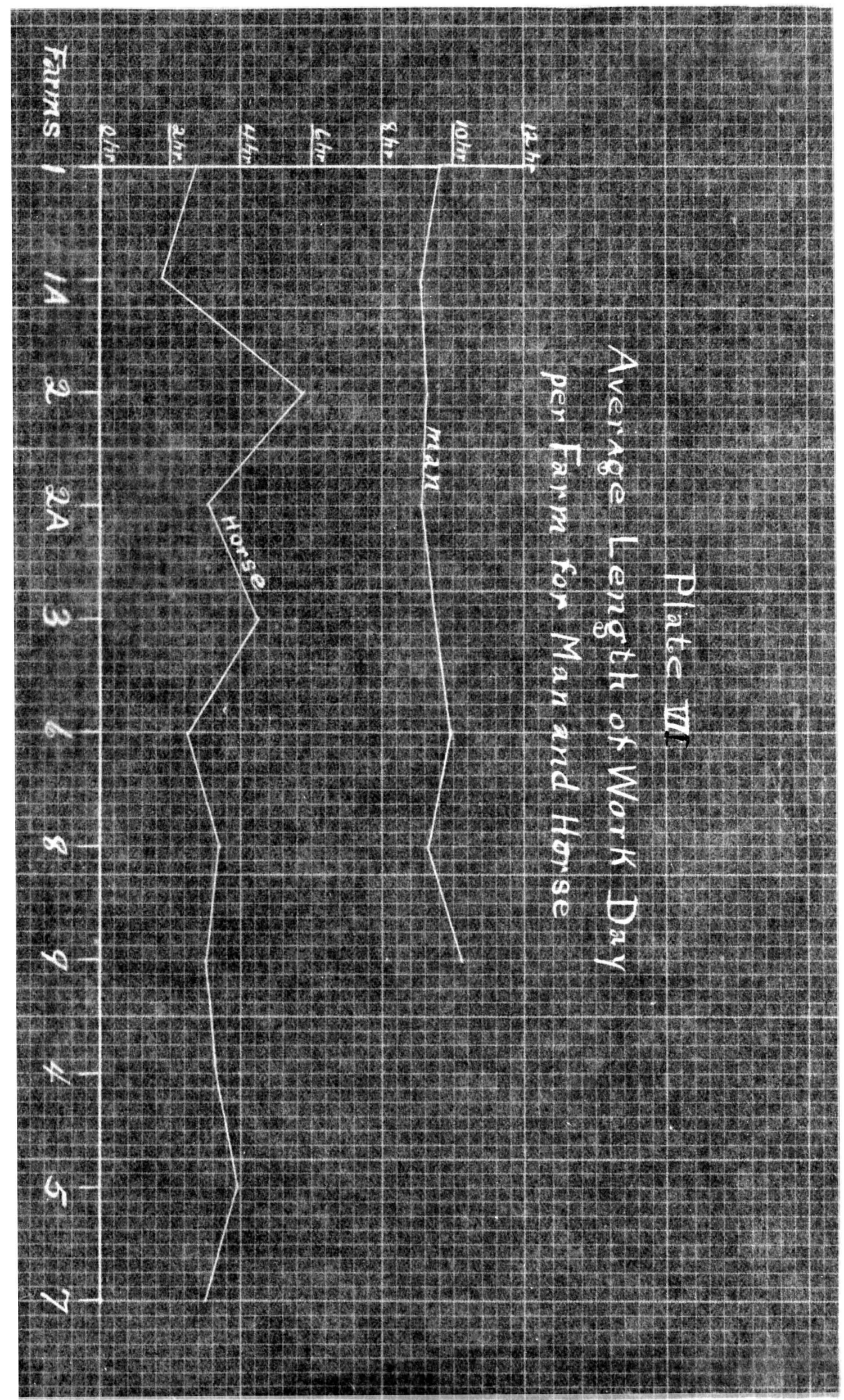


cows $\$ 1.00$ per month, and for sows $20 \%$ per month.

Table No. XI deals with the cost of keep of work horses and cost of work horse labor, and brings out several interesting points. The labor cost includes both man and horse labor; the miscellaneous cost includes interest on investment, taxes, shoeing, medicine etc. The average feed cost is $\$ 62.29$, or $76 \%$ of the total cost. The miscellaneous and labor costs are practically the same, the total cost being $\$ 81.91$. The average number of hours worked per horse per year is in round numbers 1,000, while the average cost per hour is $8.2 \phi$, a figure lower than is usually considered. It is interesting to note some of the individual farm records. Farm No. 3 has a total cost per work animal of \$121.46. Bach horse worked on an average 1414 hours which makes the cost per hour only $8.6 \phi$, a little above the average. The total cost per horse on Farm No. 1 , is $\$ 83.82$, yet their labor cost $10.7 \phi$ per hour. Each horse on this farm did onIy a little more than one-half the work the horses on farm No. 3 did. Therefore, it does not matter so much what it costs to keep a work horse provided he does enough labor at a reasonable price to pay for his keop. Since the writer is acquainted with the conditions on these different farms it would be possible to explain any extensive variations in feed, labor or miscellaneous costs if space allowed, or if this was deemed of sufficient importance.

A comparison between the feed cost and the amount of labor performed per work horse per month is shown in 
TABIE NO. XI.

Cost of Keep per Work Horse, and cost of Horse Labor per Farm.

51 horses

\begin{tabular}{|c|c|c|c|c|c|c|}
\hline $\begin{array}{l}\text { Farm } \\
\text { Io. }\end{array}$ & $\begin{array}{l}\text { Feed } \\
\text { cost }\end{array}$ & $\begin{array}{l}\text { Iabor } \\
\text { cost }\end{array}$ & $\begin{array}{l}\text { Misc } \\
\text { cost }\end{array}$ & $\begin{array}{l}\text { Total } \\
\text { cost }\end{array}$ & $\begin{array}{l}\text { Hours } \\
\text { worked }\end{array}$ & $\begin{array}{l}\text { Cost per } \\
\text { hour. }\end{array}$ \\
\hline 1. & 69.82 & 8.15 & 5.85 & 83.82 & 782 & 10.7 \\
\hline $2 \mathrm{~A}$ & 42.00 & 6.70 & 5.45 & 54.15 & 564 & 9.6 \\
\hline 2. & 64.60 & 18.60 & 14.15 & 97.35 & 1480 & 6.6 \\
\hline $2 \mathrm{~A}$ & 48.12 & 15.60 & 6.41 & 70.13 & 975 & 7.3 \\
\hline 3. & 92.37 & 9.34 & 19.75 & 121.46 & 1414 & 8.6 \\
\hline 4. & 47.86 & 9.15 & 8.75 & 65.76 & 1036 & 6.5 \\
\hline 5 . & 65.17 & 14.15 & 10.70 & 90.02 & 1230 & 7.3 \\
\hline 6 . & 67.51 & 6.50 & 7.83 & 81.84 & 772 & 10.6 \\
\hline 7. & 38.26 & 6.82 & 5.35 & 50.43 & 812 & 6.70 \\
\hline 8. & 48.22 & 9.75 & 7.92 & 65.90 & 1050 & 6.3 \\
\hline Average & 62.29 & 9.84 & 9.78 & 81.91 & 1002 & 8.2 \\
\hline$\%$ Cost & 76.05 & 12.01 & 11.94 & & & \\
\hline
\end{tabular}

Man labor figured at $14 \phi$ per hour.

Horse labor flgured at what it actually cost. 


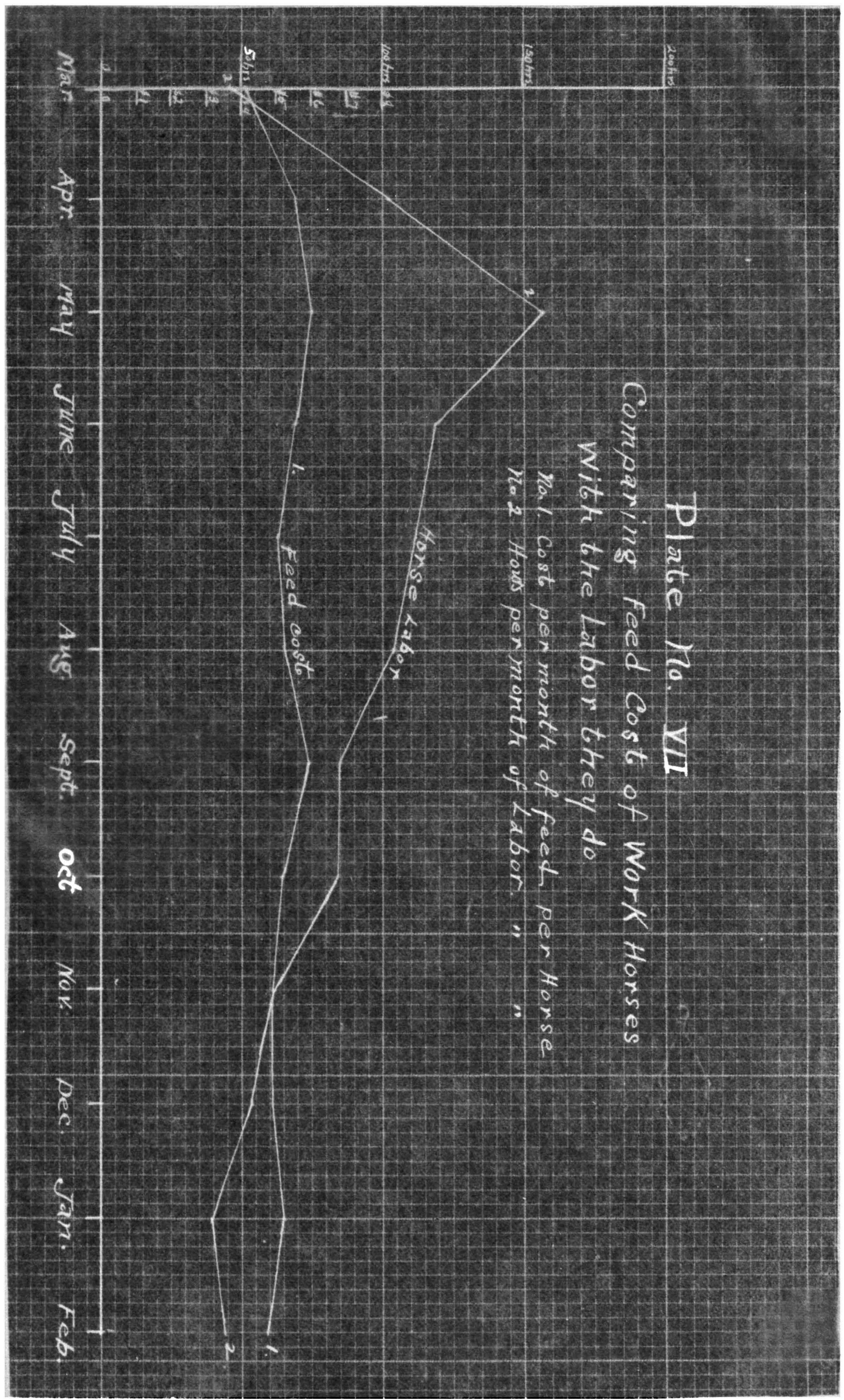


graph (Plate Ho. 6 ). It will be noticed that the feed cost is fairly uniform throughout the year while the labor varies much. Hence it costs practically the same to keep an idle horse or one that does but little work, as it does to keep a horse when he does a large amount of work.

Table No. XII shows the cost of keep per milik cow of average farm conditions, and does not apply in any way to dairy cattle. These cows were fed mostly on corn, hay, fodder and straw. It will be noticed that the feed cost is only a little more than one-half the total cost. The labor is more than one-third of the total cost and is twice as much as the labor cost per work horse.

Table No. XIII deals with the cost of keep of brood sows and is self explanatory. Not enough data was secured on this point to make the results very dependable, but it shows the possibilities nevertheless.

In table No. XIV we have shown the number of hours necessary per year to take care of the different classes of live stock. Work horses refer to the horses that are used for the farm work, while other horses include young stock and any horses not used for work purposes. Other cattle means young stock, fattening stock, males etc. It will be noticed that the milch cow requires 110 hours per year. Huch more time is needed for her than other animals because of time spent in milking. These figures include only the average farm milch cow. For dairy cows, considerable more time is needed. There is not so much variation in the number of horse hours 
TABIR HO XII.

Gost of Keep per Milch How.

\section{Gows.}

\begin{tabular}{|c|c|c|c|c|}
\hline $\begin{array}{l}\text { farm } \\
\text { Io. }\end{array}$ & $\begin{array}{l}\text { reed } \\
\text { cost }\end{array}$ & $\begin{array}{l}\text { Iabor } \\
\text { cost }\end{array}$ & $\begin{array}{r}\text { M18c } \\
\text { cost } \\
\end{array}$ & $\begin{array}{r}\text { Total } \\
\text { cost }\end{array}$ \\
\hline 1. & 30.69 & $31 \cdot 24$ & 3.23 & 65.16 \\
\hline IA & 31.93 & 25.53 & 3.15 & 60.61 \\
\hline $2 A$ & 32.00 & 15.48 & 4.15 & 51.63 \\
\hline 4 & 15.71 & 7.52 & 2.73 & 25.96 \\
\hline 5. & 44.10 & 29.00 & 3.33 & 76.43 \\
\hline 7 & 23.45 & 14.24 & 2.98 & 40.67 \\
\hline Ave. & 26.81 & 18.06 & 3.08 & 47.95 \\
\hline$\%$ cost & 55.92 & 37.66 & 6.42 & \\
\hline
\end{tabular}


TABIE NO - XIII.

Gost of Keep per Brood Sow.

\begin{tabular}{|c|c|c|c|c|}
\hline \multicolumn{3}{|c|}{39 sows } & \multicolumn{2}{|c|}{4 Farms } \\
\hline $\begin{array}{l}\text { Farm } \\
\text { No. }\end{array}$ & $\begin{array}{l}\text { Feed } \\
\text { cost }\end{array}$ & $\begin{array}{l}\text { Iabor } \\
\text { cost }\end{array}$ & $\begin{array}{r}\text { M1s0 } \\
\text { cost }\end{array}$ & $\begin{array}{l}\text { Total } \\
\text { cost }\end{array}$ \\
\hline $1 \mathrm{~A}$ & 24.20 & $2 \cdot 86$ & 1.85 & 28.91 \\
\hline 2A & 10.54 & $2 \cdot 70$ & 1.32 & $* 14.56$ \\
\hline 3 & 18.57 & 6.87 & 3.31 & 28.75 \\
\hline 5. & 21.87 & 5.62 & 3.94 & 31.43 \\
\hline Ave. & $18 \cdot 79$ & 4.52 & 2.60 & 25.91 \\
\hline of tost & 72.52 & 17.44 & 10.04 & \\
\hline
\end{tabular}

* Rye was used for winter pasture which partly accounts for the Iow cost on this farm. 


\section{TABIS NO . XIV.}

Number of man and horse hours put in per year per animal on the different classes of live stock.

\begin{tabular}{lcccc}
\hline Class & $\begin{array}{c}\text { Number } \\
\text { farms }\end{array}$ & $\begin{array}{l}\text { Number } \\
\text { antmals }\end{array}$ & $\begin{array}{c}\text { Man Iabor } \\
\text { Hrs.per Ani. }\end{array}$ & $\begin{array}{c}\text { Horse Iabor } \\
\text { Hrs.per An1. }\end{array}$ \\
\hline $\begin{array}{l}\text { Work } \\
\text { horses }\end{array}$ & 10 & 50 & 63.4 & 6.2 \\
$\begin{array}{l}\text { Other } \\
\text { horses }\end{array}$ & 5 & 22 & 30.7 & 6.5 \\
$\begin{array}{l}\text { Milch } \\
\text { cows }\end{array}$ & 7 & 22 & 110.0 & 6.0 \\
$\begin{array}{l}\text { Other } \\
\text { cattle }\end{array}$ & 4 & 23 & 23.6 & 8.2 \\
$\begin{array}{l}\text { Sows } \\
\begin{array}{l}\text { Stock } \\
\text { hogs }\end{array}\end{array}$ & 5 & 45 & 27.2 & 2.7 \\
Sheep & 4 & 240 & 9.2 & 3.6 \\
\hline
\end{tabular}

TABIE NO. XV.

Iabor cost per acre of different crops.

\begin{tabular}{lrccc}
\hline \hline Crops. & $\begin{array}{r}\text { Number } \\
\text { acres }\end{array}$ & $\begin{array}{c}\text { Man hours } \\
\text { per acre }\end{array}$ & $\begin{array}{c}\text { Horse hours } \\
\text { per acre. }\end{array}$ & cost \\
\hline Corn & 296.5 & 20.7 & 35.5 & $\$ 6.10$ \\
Wheat & 95.0 & 11.6 & 21.7 & 3.58 \\
Oats & 108.25 & 10.28 & 22.1 & 3.43 \\
Soy beans & 24.00 & 12.48 & 26.45 & 4.13 \\
Cow peas & 12.00 & 13.17 & 29.9 & 4.53 \\
Clover \& & & & & 1.77 \\
Timothy & 67.5 & 7.4 & 8.1 & \\
\hline
\end{tabular}

Man labor figured at $14 \&$ per hour.

Horse labor figured at $9 \varnothing$ per hour. 
as there is in man hours, however, more horse hours are required for other cattle than for cows and for stock hoge than for sowg. This is just opposite to the man hour requirement. This is due mainly to the fact that feed such as fodder, hay and corn is hauled out for stock cattle and for hogs, while cows and sows are usually fed in or about the barn by hand.

\section{COST OF PRODUCTION.}

Following are given a few tables that deal with the labor cost of producing different farm crops, and also the labor cost of different operations. The labor cost will be falrly uniform throughout the state. After having secured a rellable figure for this cost the total cost of production can readily be found by adding thereto the seed, fertilizer, equipment and use of land cost. The seed cost will be fairly uniform while the fertilizer cost will, of course, rary with the amount applied. The equipment cost will vary more or less with the amount invested in equipment, while the use of land cost will vary with the price of land. The labor cost of production is an important figure to know because, then, the required amount of labor for the year that will be needed for any rotation can be closely estimated beforehand. Not only the total labor cost per acre of the different crops for the year is found, but the labor cost per month also. This enables us to tell in advance how much labor per month will be required. The labor required for the field crops, together with that needed for the care of live stock and that needed for 
miscellaneous operations, will give the total amount of labor required for the farm.

Tables No. XV and XVI deal with the cost of producing different crops and the cost of different field operations respectively, and each table is self explanatory. The results shown in these tables are very dependable and probably will not miss the average far. They agree very favorably with similar figures tabulated from the Detailed Daily Record System. Any wide differences are easily explained by being acquainted with actual conditions on the farms concerned. The labor required for a corn crop may be divided into three portions, namely, that spent in preparing the seed bed and planting, in cultivation and in harvesting. This comparison is shown in table No XVII. The man labor increases with each succeeding operation while horse labor decreases. This division divides the labor devoted to the corn crop almost into thirds. One-third of the total labor, both man and horse, is required in cultivation, a little less than one-third of the man labor is needed for preparation of seed bed and planting and a little more for harvesting, while in case of the horse labor it is just opposite.

In table No. XVIII we have a comparison of the time required for the different methods of harvesting corn. The amount of man labor reguired increases materlally, as would be expected, with the following three methods of harvesting: shucked from the stalk, cut and shocked, put in silo or shredded. The same amount of horse labor is required for that shucked and for that put in the silo, while less is needed. 
TABIE NO - XVI .

Iabor Cost of Field Operations.

\begin{tabular}{|c|c|c|c|c|c|}
\hline Operations & $\begin{array}{l}\text { Number } \\
\text { of farms }\end{array}$ & Acres & $\begin{array}{l}\text { Man hours } \\
\text { per acre. }\end{array}$ & $\begin{array}{l}\text { S Horse hrs. } \\
\text { - per acre }\end{array}$ & $\begin{array}{c}\text { Cost } \\
\text { per acre. }\end{array}$ \\
\hline Ploughing & 11 & 417 & 4.5 & 12.6 & $\$ 1.76$ \\
\hline Harrowing & 10 & $403 \frac{1}{2}$ & .55 & 1.8 & .24 \\
\hline Discing & 9 & $398 \frac{1}{2}$ & 1.2 & $4 \cdot 2$ & .55 \\
\hline Dragging & 2 & 44 & .81 & $2 \cdot 4$ & .33 \\
\hline $\begin{array}{l}\text { Drilling } \\
\text { small grain }\end{array}$ & 9 & $305 \frac{1}{2}$ & .94 & $2 \cdot 5$ & .36 \\
\hline Planting corn & 11 & 278 & 1.5 & 2.5 & .43 \\
\hline $\begin{array}{l}\text { Cultivating } \\
\text { corn }\end{array}$ & 11 & 955 & 1.5 & 3.1 & .49 \\
\hline $\begin{array}{l}\text { *Harvesting } \\
\text { corn }\end{array}$ & 7 & 125 & 5.3 & 9.5 & 1.60 \\
\hline $\begin{array}{l}\text { Cutting } \\
\text { small grain }\end{array}$ & 6 & $115 \frac{1}{2}$ & 1.37 & $4 \cdot 15$ & .57 \\
\hline cutting hay & 8 & $146 \frac{1}{2}$ & 1.1 & 2.3 & .36 \\
\hline
\end{tabular}

This harvesting includes only corn that was shucked or snapped from the stalk.

Rate :

Man labor $14 \phi$ per hour.

Horse labor $9 \phi$ per hour. 
TABIE NO. XVII.

Comparison of Time Spent in Preparation of Seed-bed and Planting, Cultivating, and Harvesting of the corn crop.

\begin{tabular}{lcccc}
\hline & $\begin{array}{c}\text { Number of } \\
\text { fields. }\end{array}$ & $\begin{array}{c}\text { Number of } \\
\text { acres. }\end{array}$ & $\begin{array}{c}\text { Man hours } \\
\text { per acre }\end{array}$ & $\begin{array}{c}\text { Horse hours } \\
\text { per acre. }\end{array}$ \\
\hline $\begin{array}{l}\text { Preparation } \\
\text { of seed-bed }\end{array}$ & & & & \\
\& planting. & 20 & $272 \frac{1}{2}$ & 6.5 & 16.2 \\
Cultivating & 20 & $272 \frac{1}{2}$ & 7.3 & 12.3 \\
Harvesting & 20 & $272 \frac{1}{2}$ & 8.0 & 8.7 \\
\hline
\end{tabular}

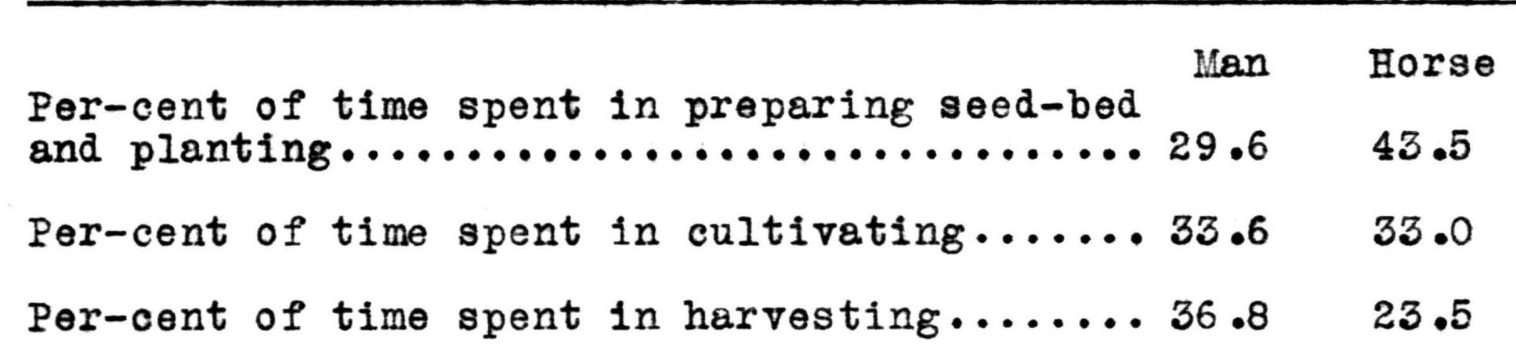

\section{TABLE NO. XVIII.}

Comparing Different Methods of Harvesting Corn.

\begin{tabular}{lcccc}
\hline & $\begin{array}{c}\text { Number of } \\
\text { fields. }\end{array}$ & $\begin{array}{c}\text { Number of } \\
\text { acres. }\end{array}$ & $\begin{array}{c}\text { Man hours } \\
\text { per acre. }\end{array}$ & $\begin{array}{c}\text { Horse hours } \\
\text { per acre. }\end{array}$ \\
\hline $\begin{array}{c}\text { Shucked } \\
\text { from stalk. }\end{array}$ & 12 & $174 \frac{1}{2}$ & 6.4 & 9.2 \\
* Cut \& shocked & 5 & 65 & 10.5 & 7.0 \\
$\begin{array}{l}\text { Put in Silo } \\
\text { or shredded }\end{array}$ & 3 & 33 & 12.5 & 9.2 \\
\hline
\end{tabular}

* Tut by hand or sled.

"Two fields put in Silo, and one shredded. 
where corn is cut and shocked.

A comparison of the labor required on different size fields may be made with all crops. Table No. XIX shows such a comparison with corn. The man labor in each case decreases considerable as size of field increases, while horse labor remains almost the same. With larger fields will be used larger machinery, and hence more horse labor required. The amount of work done will increase in proportion to added horse labor, which partly accounts for the uniformity in horse labor. But what has influenced these figures most is because three of the six fields of twenty acres and over in size were on the same farm, and for some reason or other the labor on this farm devoted to corn was exceedingly low. The data that is shown here, in reference to the corn crop, could as easily be secured for any and all other crops if such were desired.

In table no. $X X$ is given the total cost of corn and wheat per acre. The labor cost was taken from table No. XV, and shows considerable more on corn than on wheat. Corn should require more labor but the difference here is very likely too great; the labor on wheat no doubt is a little low. The use of land for corn is slightly greater than for wheat, due no doubt to the fact that better land is most always used for corn. Any figure, however, that pretends to show the total cost of production of any crop can at best be only approximate. The labor cost, which at first seems to be the most staple of the different costs, is found to vary widely on different farms with different systems of farming For instance, in preparing the seed bed, some will disc 
TABIE NO . XIX.

Comparing Different Size Corn Fields.

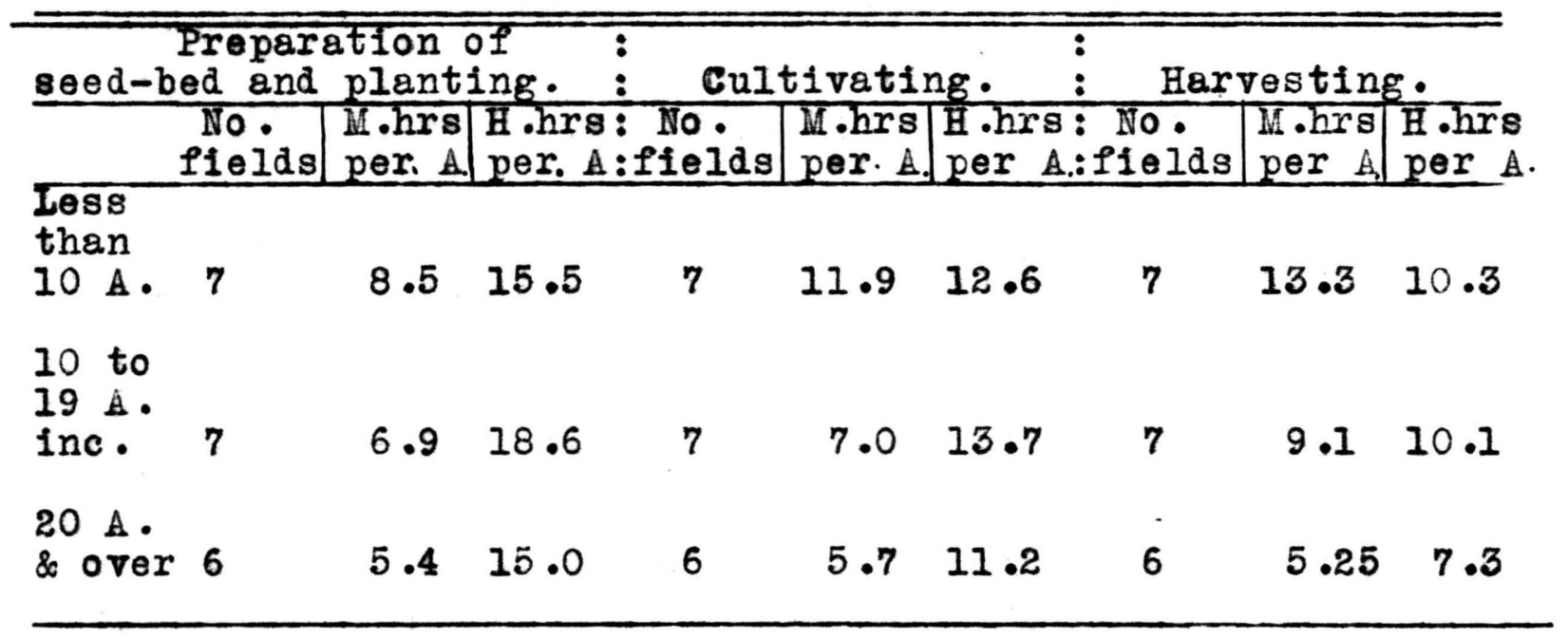

The average size of fields in the different classes above are $7.6,12.1,22.5$ acres respectively.

TABIE NO . XX.

Total Cost of Production of theat and corn.

\begin{tabular}{lrrrrrr}
\hline \hline Crop & $\begin{array}{r}\text { Labor } \\
\text { cost }\end{array}$ & Fert'z & Seed & $\begin{array}{c}\text { Equip- Twine \& } \\
\text { ment. }\end{array}$ & Use of & \\
Corn. $\$ 6.10$ & .18 & .21 & .81 & & 6.00 & 13.30 \\
Wheat. 3.58 & & 1.09 & .27 & 1.04 & 5.30 & 11.28 \\
\hline
\end{tabular}

Corn $193 \frac{1}{2}$ acres.

Wheat 78 acres. 
or double a180, plough and double harrow, while others will not disc at all and probably harrow but once; some will cultivate corn three times, others four or flve times: some corn will be hogged down, some snapped and shucked, and some put into the 8110. In case of cow-peas, for example, some people cultivate and some do not; and in case of oats, some thresh them while others feed in the sheaf. These things make the figure that would tell us the total cost of producing a crop, so uncertain that it does not mean a great deal. There is a way however, of getting at the labor cost of a crop, and that 1s, first, to find the cost of the several operations as ploughing, harrowing, discing, cultivating, binding, shocking otc. such cost can be applied to the system of handing any crop, and the total labor cost almogt accurately secured.

In tables 10. XII and XXI, are given the number of man and horge hours respectively that are required per acre for the different erops per month. This is a part of the study of seasonal distribution of labor, and with such tables one can determine in advance how much labor will be required throughout the jear to handle anj given rotation.

In attempting to point out what valuable data can be secured from the Diary Record System, this paper has dealt almost entirely with the cost of production, and but slightly with seasonal distribution of labor. Production could be gone into much more in detall. The distribution of labor has hardy been touched. Other things of interest that could be brought out are: the number of crop acres per workman, 
IABOR DISTRIBUTION.

TABIE NO . XXI.

Man Hours per Acre.

\begin{tabular}{|c|c|c|c|c|c|c|}
\hline Month. & Corn. & Oats. & Wheat. & $\begin{array}{l}\text { Timothy } \\
\text { \& clover. }\end{array}$ & $\begin{array}{l}\text { Soj } \\
\text { beans. }\end{array}$ & $\begin{array}{c}\text { Corn } \\
\text { hogged. }\end{array}$ \\
\hline $\begin{array}{l}\text { Maroh } \\
\text { April } \\
\text { May } \\
\text { June } \\
\text { July } \\
\text { Aug. } \\
\text { Sept. } \\
\text { Oot. } \\
\text { Nov. } \\
\text { Dec. } \\
\text { Jan. } \\
\text { Peb. }\end{array}$ & $\begin{array}{r}.15 \\
1.31 \\
5.15 \\
4.70 \\
2.42 \\
.19 \\
1.58 \\
1.76 \\
2.26 \\
.93 \\
.61 \\
.30\end{array}$ & $\begin{array}{r}.67 \\
3.21 \\
.22 \\
4.26 \\
1.59 \\
.06\end{array}$ & $\begin{array}{r}.13 \\
.19 \\
5.52 \\
2.54 \\
1.26 \\
2.14\end{array}$ & $\begin{array}{r}3.02 \\
3.59 \\
.46 \\
1.31\end{array}$ & $\begin{array}{c}7.05 \\
3.14 \\
2.60 \\
1.65 \\
.50 \\
.58 \\
.125 \\
.28\end{array}$ & $\begin{array}{l}3.04 \\
8.10 \\
4.25 \\
1.14\end{array}$ \\
\hline
\end{tabular}

TABIE 10 . XXII .

Horse Hours per Acre.

\begin{tabular}{|c|c|c|c|c|c|c|}
\hline Month. & Corn. & Oats. & Wheat. & $\begin{array}{l}\text { Iimothy } \\
\& \text { clover. }\end{array}$ & $\begin{array}{c}\text { Soy } \\
\text { boans. }\end{array}$ & $\begin{array}{c}\text { Corn } \\
\text { hogged. }\end{array}$ \\
\hline $\begin{array}{l}\text { March. } \\
\text { April. } \\
\text { May. } \\
\text { June. } \\
\text { July. } \\
\text { Aug. } \\
\text { Sept. } \\
\text { Oot. } \\
\text { Nov. } \\
\text { Dec . } \\
\text { Jan. } \\
\text { Feb. }\end{array}$ & $\begin{array}{r}.33 \\
3.94 \\
12.87 \\
8.10 \\
3.16 \\
.05 \\
.81 \\
2.00 \\
3.63 \\
1.42 \\
.67 \\
.38\end{array}$ & $\begin{array}{r}1.34 \\
10.00 \\
.77 \\
6.09 \\
2.58 \\
.22\end{array}$ & $\begin{array}{l}.53 \\
.26 \\
6.68 \\
5.25 \\
2.64 \\
6.38\end{array}$ & $\begin{array}{r}2.67 \\
4.55 \\
.89 \\
1.04\end{array}$ & $\begin{array}{r}11.10 \\
7.03 \\
3.12 \\
2.46 \\
1.21 \\
.92 \\
.25 \\
.35\end{array}$ & $\begin{array}{r}11.30 \\
17.85 \\
8.07 \\
1.63\end{array}$ \\
\hline
\end{tabular}


number of animal units per farm acre, the farm incomes compared with size of farm, system of farming, etc., the amount of mortgages carried and a number of other important things which are useless to mention here.

In order to give the farmer a chance to make his testimony in favor of the Farm Diary. I enclose herewith some actual quotations taken from letters received from co-operators. These expressions have been entirely voluntary and only incidentally inserted into business letters written to the Department.

"I have my diary record up to date and find it much easier than the system I used last year."

"I find your book becoming more valuable as I become better educated as to its leadings."

"I feel that as I grow into the use of this record it is going to prove of great value to me."

"My record book and your requirements are proving invaluable to me, for while I have kept a daily journal for years, yet this is the first year that I am able to systematically sum up the full results."

"I am well pleased with account book as we can tell from month to month just what we are doing." 
C. ON C I US I O N

Both from the standpoint of the farmer who keeps it and the investigator who tabulates the results, the Farm Diary is a rapid and efficient means of collecting data for investigational purposes.

By taking the figures given here as sufficient in number to give worthy conclusions, the following represents some of the facts pertaining to Missouri farming conditions.

A man works on an average of 9.5 hours per day for the year. His heaviest month is June with 10.3 hours per day, and his lightest month is Harch with 7.6 hours.

A horse works on an average of 3.26 hours per day; from 1.5 hours in January to 5.7 hours in May. It costs practically as much to keep work horses in the winter months when little work is done as it does in the crop season.

The feed cost of a work horse is $\$ 62.29$, the total cost $\$ 81.91$, and the cost of horse labor is 8.2 cents per hour.

The feed cost to keep a milch cow is $\$ 26.81$, and the total cost $\$ 47.95$.

The feed cost for a brood sow is $\$ 18.79$ and her total cost is $\$ 25.91$.

The labor cost per acre of producing crops is as 
follows: Corn, $\$ 6.10$, wheat, and oats are practically the same with $\$ 3.58$ and $\$ 3.43$ respectively; cowpeas and soybeans about the same with $\$ 4.53$ and $\$ 4.13$ respectively, timothy and clover, $\$ 1.77$ per acre.

The cost of field operations per acre is as follows: Plowing, $\$ 1.76$, harrowing .24, discing .36, planting corn .43, cultivating corn .49 , harvesting corn $\$ 1.60$, cutting small grain .57, cutting hay .36.

only a few of the outstanding results are indicated in this summary. 